\title{
Review \\ The Endocannabinoid System: A Bridge between Alzheimer's Disease and Gut Microbiota
}

\author{
Tiziana Bisogno ${ }^{1, * \mathbb{D}}$, Anna Lauritano ${ }^{2}$ and Fabiana Piscitelli ${ }^{2, *(\mathbb{D}}$ \\ 1 Endocannabinoid Research Group, Istituto di Farmacologia Traslazionale, Consiglio Nazionale Delle \\ Ricerche, Area Della Ricerca di Roma 2 Via Fosso del Cavaliere 100, 00133 Roma, Italy \\ 2 Endocannabinoid Research Group, Istituto di Chimica Biomolecolare, Via Campi Flegrei 34, \\ 80078 Pozzuoli, Italy; anna.lauritano@icb.cnr.it \\ * Correspondence: tiziana.bisogno@ift.cnr.it (T.B.); fpiscitelli@icb.cnr.it (F.P.)
}

check for updates

Citation: Bisogno, T.; Lauritano, A.; Piscitelli, F. The Endocannabinoid System: A Bridge between Alzheimer's Disease and Gut Microbiota. Life 2021, 11, 934. https://doi.org/10.3390/ life11090934

Academic Editor: Paola Grimaldi

Received: 3 August 2021

Accepted: 4 September 2021

Published: 8 September 2021

Publisher's Note: MDPI stays neutral with regard to jurisdictional claims in published maps and institutional affiliations.

Copyright: (c) 2021 by the authors. Licensee MDPI, Basel, Switzerland. This article is an open access article distributed under the terms and conditions of the Creative Commons Attribution (CC BY) license (https:// creativecommons.org/licenses/by/ $4.0 /)$.

\begin{abstract}
Alzheimer's disease (AD) is a neurodegenerative disease that progresses from mild cognitive impairment to severe dementia over time. The main clinical hallmarks of the disease (e.g., beta-amyloid plaques and neurofibrillary tangles) begin during preclinical AD when cognitive deficits are not yet apparent. Hence, a more profound understanding of AD pathogenesis is needed to develop new therapeutic strategies. In this context, the endocannabinoid (eCB) system and the gut microbiome are increasingly emerging as important players in maintaining the general homeostasis and the health status of the host. However, their interaction has come to light just recently with gut microbiota regulating the $\mathrm{eCB}$ tone at both receptor and enzyme levels in intestinal and adipose tissues. Importantly, eCB system and gut microbiome, have been suggested to play a role in AD in both animal and human studies. Therefore, the microbiome gut-brain axis and the eCB system are potential common denominators in the $\mathrm{AD}$ physiopathology. Hence, the aim of this review is to provide a general overview on the role of both the eCB system and the microbiome gut-brain axis in $\mathrm{AD}$ and to suggest possible mechanisms that underlie the potential interplay of these two systems.
\end{abstract}

Keywords: endocannabinoid system; microbiota; Alzheimer's disease; gut-brain axis

\section{Introduction}

Alzheimer's disease (AD) is a chronic age-related progressive neurodegenerative disorder accounting for $\sim 80 \%$ of dementia globally. Despite decades of intensive research, AD remains incurable and is still a challenge for global health. Indeed, current therapies provide only symptomatic relief and promising preclinical results have repeatedly failed in phase III clinical trials. Thus, the full understanding of the disease pathogenesis and the identification of therapeutic strategies that may prevent or delay disease progression appear urgent [1].

In this scenario, increasing interest has been focused on the gut microbiome and the endocannabinoid $(\mathrm{eCB})$ system as emerging targets involved in the control of AD.

The community of bacteria, yeast, archaea, viruses, protozoa, and parasite that inhabit human gastrointestinal (GI) tract, collectively known as microbiota, undergoes dynamic changes throughout life [2]. An increasing number of studies have explored a possible bidirectional connection between gut microbiota and the brain, for which the term gutbrain axis has been coined [3,4]. Moreover, the link between the gut microbiota and human diseases is more and more evident as alterations in gut microbial community composition have been reported in several pathological conditions including neurological and autoimmune disorders, obesity and cancer [5-10]. The microbiome studies on a transgenic AD model and patients highlighted alterations in gut microbiota providing new understanding of AD and additional features for its pathological characterization [11,12]. On the other hand, the eCB system that is ubiquitously expressed throughout the gut, 
periphery and brain is now well recognized to participate in almost all human physiological processes and to be involved in several pathological conditions [13-16].

Studies performed in both AD-like animal models and patients suggested that eCB system alterations are associated with $\mathrm{AD}$ pathophysiology, and that its pharmacological modulation may have disease-modifying effects $[17,18]$. In the last few years, the interconnection of the $\mathrm{eCB}$ system and the gut microbiota has been addressed and different aspects of regulation and dysregulation of the gut microbiome and eCB system mainly in obesity and metabolic disorders excellently reviewed $[19,20]$. Recently, the eCB system and the gut microbiota dysfunctions were also reported in neuropsychiatric disorders $[21,22]$.

In this review, we first provide an overview of the microbiota gut-brain axis and the eCB system, then we consider the crosstalk between the gut microbiota and the eCB system or AD physiopathology. Finally, we discuss the potential connection between the eCB system and the gut-brain axis in AD.

\section{The eCB System and the Endocannabinoidome}

The eCB system has classically been described as a complex pleiotropic system comprised of two cannabinoid responsive G-protein-coupled receptors referred as the eCB receptor type- 1 and type-2 $\left(\mathrm{CB}_{1}\right.$ and $\left.\mathrm{CB}_{2}\right)$, endogenous lipid-derived ligands for such receptors, known as eCBs, and at least five enzymes responsible for eCB biosynthesis and degradation [23]. The two most studied eCBs are $N$-arachidonoylethanolamine (AEA), also known as anandamide, and 2-arachidonoylglycerol (2-AG) which belong to the $\mathrm{N}$-acylethanolamine (NAEs) and 2-monoacylglycerol (2-MAGs) families, respectively [24] (Figure 1). Unlike classical neurotransmitters, or many other intracellular signaling molecules, which are stored in vesicles before to be released, AEA and 2-AG are synthesized "on demand" from arachidonic acid (AA) in a cell and time-specific manner through enzymatic activation by multiple pathways in membrane of different cell types such as neurons, adipocytes, and skeletal muscle cells, in response to increased intracellular $\mathrm{Ca}^{2+}$ concentration, membrane depolarization, and/or receptor stimulation $[25,26]$. In brief, AEA is biosynthesized from the hydrolysis of $N$-acyl-phosphatidylethanolamines (NAPE) by NAPE-specific phospholipase D-like enzyme (NAPE-PLD) or via other routes not involving NAPE-PLD [27]. On the other hand, 2-AG is produced from the hydrolysis of diacylglycerol (DAG), by either DAG lipase- $\alpha$ or $-\beta$ (DAGL- $\alpha$ or $-\beta$ ), although most 2-AG mediating synaptic transmission in adult brain is generated mostly by DAGL$\alpha[28,29]$. However, AEA and 2-AG are inactivated in respective target tissues differently. Indeed, AEA is hydrolyzed to AA and ethanolamine by fatty acid amide hydrolase (FAAH), whereas 2-AG is mostly hydrolyzed by MAG lipase (MAGL) into AA and glycerol [30,31]. It is well recognized that $\mathrm{eCBs}$ modulate retrograde signaling in the brain, providing a mechanism for inhibitory feedback to regulate neurotransmitter release $[32,33]$. This unique function of $\mathrm{eCBs}$ suggested their investigation as therapeutic targets for human diseases affecting central nervous system (CNS) [13]. Indeed, the eCB system dysregulation in the CNS has been increasingly implicated in the physiopathology of neurodegenerative and neuropsychiatric disorders, such as AD [18], Parkinson's disease [34], Huntington's disease [35], multiple sclerosis [36] schizophrenia [37] and anxiety disorders [38].

$\mathrm{CB}_{1}$ and $\mathrm{CB}_{2}$ are differently expressed throughout human body and their distribution correlated with their specific physiological roles. The $\mathrm{CB}_{1}$ is the most abundant and widespread GPCR in the mammalian CNS but it is also expressed in non-neuronal peripheral tissues, including the gut, where it is involved in the nociception, adipogenesis and pro-inflammation processes [39]. On the other hand, $\mathrm{CB}_{2}$ is prevalent in the periphery, particularly within immune cells including microglia, but its expression in neurons is still enigmatic $[38,40] \cdot \mathrm{CB}_{2}$ activation reduces inflammatory mediator release and it seems to be the main target for inflammation-dependent neurodegeneration [41]. Interestingly, $\mathrm{CB}_{1}$ and $\mathrm{CB}_{2}$ are not the only receptors whose activity are responsive to $A E A$ and 2-AG, as both ligands are able to modulate other GPCRs such as GPR-18, GPR-55 and GPR-119, the thermosensitive transient receptor potential cation channels, such as the 
vanilloid type-1 (TRPV1), as well as peroxisome proliferator-activated receptor- $\alpha$ and $-\gamma$ (PPAR- $\alpha$ and $-\gamma$ ) [39]. The identification of a continuous increasing number of bioactive long chain fatty acid amides having eCB-like properties, such as other NAEs, including $N$-palmitoylethanolamine (PEA) and $N$-oleylethanolamine (OEA) or $N$-acyl amino acids/dopamine/taurine/serotonines, has allowed to expand the concept of the eCB system towards the "endocannabinoidome" (eCBome) [42]. This new plethora of bioactive compounds share with eCBs metabolic pathways and molecular targets, not only $\mathrm{CB}_{1}$ and $\mathrm{CB}_{2}[20,43]$, but also GPR-55, TRPV1 and PPAR [44,45] mimicking the physiological features of eCBs.

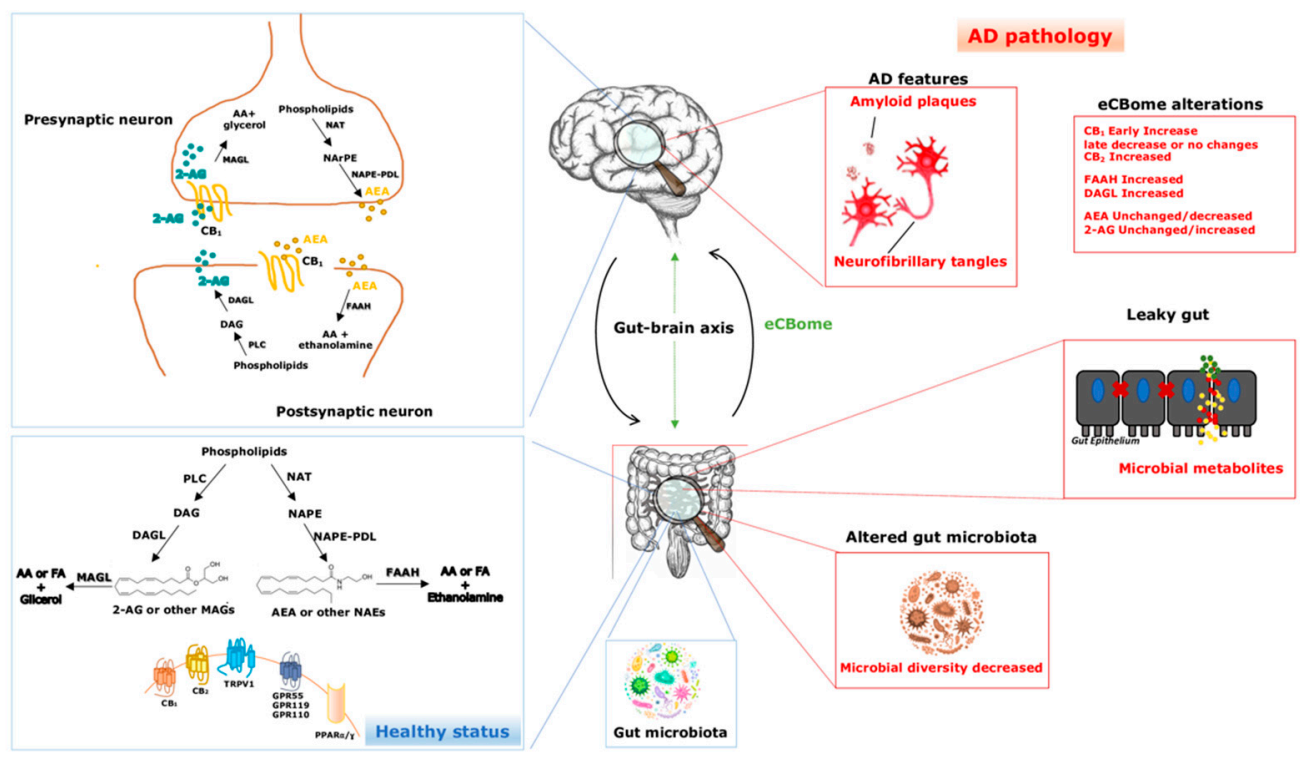

Figure 1. The endocannabinoidome and the gut-brain axis in physiological conditions and in Alzheimer's disease. Blue lines indicate a healthy status, though red lines indicate AD pathology. Green arrows denote the bidirectional interplay between the eCBome and the gut-brain axis. eCBome - endocannabinoidome; AD—Alzheimer's disease; AEA—anandamide; 2-AG-2-arachidonoylglycerol; NAEs-N-acylethanolamines; MAGs-monoacylglycerols; AAarachidonic acid; FA—fatty acids; PLC—phospholipase C; DAGL—diacylglycerol lipase; MAGL— monoacylglycerol lipase; NArPE- $N$-arachidonoyl-phosphatidylethanolamine; NAPE-N-acylphosphatidylethanolamine; NAPE-PLD—NAPE-specific phospholipase D-like enzyme; NAT-Nacyl-transferase; FAAH—fatty acid amide hydrolase; $\mathrm{CB}_{1}$ and $\mathrm{CB}_{2}$ - cannabinoid receptor type-1 and 2; TRPV1-transient receptor potential cation channels, such as the vanilloid type-1; GPR55, GPR119 and GPR110 G-protein-coupled receptor 55, 119 and 110; PPAR $\alpha$ and PPAR $\gamma$ - peroxisome proliferator-activated receptor- $\alpha$ and $-\gamma$.

\section{Microbiota Gut-Brain Axis: Background}

\subsection{Gut Microbiome}

In the past few decades, the scientific community has increased its interest in the microbiome and how it may impact our daily lives. Human microbiota accounts for trillions of microorganisms that live in symbiotic balance with us [46] and is a key player of both host physiology and human health and disease. In the last decades, technological advances in sequencing methodologies and in bioinformatic tools have allowed to make great strides in terms of microbiota composition with cheaper costs than in the past. Indeed, over 10 million of genes in our body are microbial, resulting $>99 \%$ of our total genes [46-52] Gut, skin, oral cavities, eyes and the urogenital tract are the main human sites colonized by microbes. Among the others, the gut microbiota is the best known and the most studied, and its full investigation is helping to understand the microbiome role in many physiological and pathological conditions and to develop new therapeutic strategies. The GI tract is a very hospitable ground for many microbes, providing an energy rich, anaerobic 
environment in which the microbes can thrive, including not only bacteria, which are the most well characterized, but also yeasts, archaea, parasites such as helminths, viruses, and protozoa [53-57]. In this favorable environment, microbes contribute to host metabolism, protection and immune development and maintenance. Data obtained from the Human Microbiome Project and MetaHIT show that the microbiome is classified into 11 different phyla with Proteobacteria, Firmicutes, Actinobacteria and Bacteroidetes [58-60] accounting for the $90 \%$ of the total microbiome, whereas Fusobacteria and Verrucomicrobia phyla are less abundant [53].

In terms of evolution, the microbiota has been a constant companion throughout our history, living in symbiotic balance with our body. Indeed, while our genome is stable during lifetime, the microbiome is dynamic [61], different in terms of composition and abundance $[62,63]$ and affected by external inputs. After birth specific taxa are hosted in our body with high abundance of Enterobacteriaceae, Bifidobacteriaceae, and Clostridiaceae families, and low abundance of Lachnospiraceae and Ruminococcaceae [64-66]. As the baby grows the diversity in microbial families composition increases with a majority of anaerobic taxa [67-69] with a specific enrichment in pathways supporting ongoing development, which are functional for the healthy state [70]. The microbiota continues to change until adulthood and remains stable until old age if unperturbed by pathological or environmental conditions [2]. Indeed, the gut microbiota composition in the elderly decreases, and this event correlates with some age-related impairments in humans, such as frailty and cognitive deficits [71-73]. On the other hand, animal studies have shown that in old mice the diversity of microbiota composition increased in comparison to younger rodents [74]. Moreover, some studies have shown that Bacteroides/Prevotella, Eubacteriumrectale/Clostridium coccoides, and Ruminococcus prevailed in the microbiota of people aged between 70 and 100 years [75] and studies in semi-supercentenarians, from 105 to 109 years of age, showed a less abundance of Akkermansia, suggesting a specific role of the gut microbiota composition change in promoting longevity and health [76,77].

\subsection{Gut-Brain Axis Bidirectional Interplay}

The CNS and the GI are in constant communication through a bidirectional pathway, the so-called "gut-brain axis" [78,79]. This pathway integrates neural, hormonal and immunological signals that provide CNS regulation of permeability, secretion, motility, and immunity of the digestive tract [80]. The gut microbiome can affect brain functions by influencing the host metabolism and through the synthesis of biological active mediators, which in turn activate their molecular targets expressed on the afferent fibers of the vagus nerve (VN) and reduce the gut and blood-brain barrier (BBB) permeability, block the microglia and astrocyte activation triggering the gut and brain homeostasis [81,82]. The autonomic nervous system (ANS), immune system and the hypothalamic-pituitary-adrenal (HPA) axis allow the communication between gut and brain. Moreover, they can also communicate by the production of neurotransmitters and short chain fatty acids (SCFAs) [81,82].

The ANS comprises of three branches: the sympathetic, parasympathetic, and the enteric nervous system (ENS) [82], through which control GI functions [83]. In particular, the ANS drives both afferent and efferent neural signals between the gut and the brain, respectively. The ENS is located in the gut lignin and regulates mainly motor functions and secretion of the GI tract. Sympathetic and parasympathetic system communicate with CNS via prevertebral ganglia and VN, respectively. The gut microbiota produces several neuromodulators, that when released, influence CNS activities interacting with the host neurons through the afferent pathways from ENS and ANS, both locally and centrally [84]. The HPA axis is the main non-neuronal pathways within the bidirectional communication between the gut microbiome and the brain. It is a neuroendocrine coordinator of the adaptive responses against stress by releasing corticotrophin releasing factor (CRF) from the paraventricular nucleus (PVN) of the hypothalamus [83]. Interestingly, there is interplay between the VN and the HPA axis as showed by Hosoi et al. [85], via release of IL-1 $\beta$. Recent studies have shown the interaction of the gut microbiota with the CNS resident 
immune system, i.e., microglial cells, which are considered the macrophages of the brain and play a key role in the homeostasis and development of the brain [86]. Germ-free (GF) mice, which are totally devoid of bacteria, displayed global defects in microglia, which was restored by a reconstitution of the intestinal microbiota or by supplementation with SCFAs [86]. Moreover, monocyte migration induced by tumor necrosis factor-alpha (TNF- $\alpha$ ) release by activated microglia was reverted by probiotic treatment improving inflammationassociated sickness behavior $[87,88]$. The gut microbiota has been shown to synthesize and respond to host neuroendocrine signaling molecules, including catecholamines, GABA, histamine, serotonin, tryptophan and kynurenine [89] which are deeply involved in host mood and cognition. Several bacterial species, e.g., Escherichia and Bacillus produced catecholamines, while other such as Lactobacillus synthesized GABA [82]. Serotonin (5-HT) is released by enterochomaffin cells (ECs), synthesized starting from dietary tryptophan. Although studies in GF mice have demonstrated that specific gut bacterial species increase colonic 5-HT levels, via tryptophan hydroxylase-1 (TPH1) overexpression [90,91], the impossibility of 5-HT to cross the BBB suggests that variation in intestinal 5-HT levels are unlikely to produce direct effect on the brain [89,92]. However, 5-HT released by ECs may affect the gut-brain axis by modulating the gut vagal afferent activity and inflammatory responses [89]. The gut microbiota is able to control host tryptophan metabolism along the kynurenine pathway, thereby decreasing serotonin synthesis, which in turn can have an effect on disturbances associated with serotonergic neurotransmission [93]. Indeed, it has been shown kynurenine and its metabolites are implicated in mental health [94]. Interestingly, some bacterial strains are able to synthesize histamine which plays a key role in host physiology, including the regulation of immune functions and wakefulness [89]. Therefore, it seems to be well established histamine role in the regulation of the interplay host-microbe as a neuroendocrine-immune mediator [82].

SCFAs (mostly acetate, propionate and butyrate) are the most studied gut microbialderived metabolites and have a fundamental role in host physiology [95-97]. It has been shown that SCFAs gastrointestinal levels are associated with CNS disorders, such as AD or autism spectrum disorder (ASD), demonstrating their key role in the gut-brain communication $[98,99]$. SCFAs production is regulated by many different host, environmental, dietary and microbiological factors and their primary source is the microbial fermentation of specific host-indigestible dietary fibers [100]. SCFAs have been detected in human feces and in hepatocytes but only acetate has been reported to be present also in the cerebral spinal fluid (CSF) [89]. Growing body of evidence shows that gut microbial-derived SCFAs might be able to direct affect host CNS physiology. Once produced in the gut, SCFAs can therefore cross the BBB via the circulation system and influence the microglia [101]. The presence of propionate or butyrate in the brain has never been reported, however, propionate can cross the BBB and its molecular target (free fatty acid receptor-3, FFAR3) is expressed in human brain endothelium [102]. Moreover, propionate has also been detected in human saliva and its levels correlated with dementia [103] and AD [104].

\section{The Pathogenic Role of Gut Microbiota in AD}

$\mathrm{AD}$ is a fatal neurodegenerative disorder characterized by a progressive memory loss and cognitive impairment [105]. The cardinal pathological features of the AD brain are the presence of neurofibrillary tangles, intracellular lesions due to hyperphosphorylated tau protein, and senile neuritic plaques consisting of extracellular insoluble forms of amyloid- $\beta$ peptide $(A \beta)$. The latter is produced through the sequential cleavage of amyloid precursor protein (APP) by $\beta$-secretase $\beta$-site APP cleavage enzyme 1 , and the $\gamma$-secretase complex [105]. The full understanding of the pathogenesis of AD is still challenging and many hypotheses including neuroinflammation, oxidative stress, mitochondrial dysfunction, lipid metabolism, apoptosis, calcium and metal dyshomeostasis, and epigenetic changes have been proposed [106-109]. In addition, infectious agents have been found in the brain and postulated to be, through multiple mechanisms, involved in the pathogenesis of AD. In this regard, the periodontitis-associated pathogen Porphyromonas gingivalis might affect the 
development and/or progression of $\mathrm{AD}$ and therapeutic approaches aimed at counteract both periodontitis and AD are under investigation [110,111]. None of the current theories explain all the histopathological and multifactorial molecular changes described in $\mathrm{AD}$ and although tremendous efforts have been made for the treatment of AD, no efficient disease-modifying therapeutics are available. In the recent years, the microbiota-gut-brain axis has emerged as a potential therapeutic target for the treatment of several pathological conditions including, among the other, brain disorders [112], metabolic diseases [113,114] and inflammatory bowel disease [115]. Relevant preclinical and epidemiological studies have associated the common intestinal disorders constipation, diarrhea, irritable bowel syndrome (IBS), inflammatory bowel disease (IBD) and intestinal bacterial overgrowth to the increased risk in developing dementia or AD [116-118]. Several reports indicate that gut microbiota composition and activity affect the pathogenesis of AD through many pathways, including neurotransmitters, metabolites and chronic neuroinflammation. Some bacteria metabolize or produce a broad range of neurotransmitters including dopamine, 5-HT, $\alpha$-aminobutyric acid (GABA) and acetylcholine [119-122], and even though they cannot cross the protective $\mathrm{BBB}$, they might affect the physiological events in the brain through the $\mathrm{VN}$ and its afferent neurons [123]. As above reported, gut microbiota control the metabolism of the amino acid tryptophan and can decrease 5-HT availability by enhancing the pool of tryptophan available for kynurenine synthesis [93]. Acetylcholine, produced by Bacillus subtilis and Lactobacillus plantarum, can reduce the production of interleukin- 6 and $1 \beta$ (IL-6, IL-1 $\beta$ ) and TNF- $\alpha$, while dopamine, produced by Bacillus and Escherichia, modulates NLRP3 (nucleotide-binding oligomerization domain (NOD)-, leucine-rich repeat (LRR)-, and pyrin domain (PYD)-containing protein 3) inflammasome degradation and exerts anti-inflammatory or pro-inflammatory functions via activation of the dopamine receptors D1, D2 and D3, respectively [124-126]. Microbiota might modulate inhibitory/excitatory neurotransmission in CNS as Bifidobacterium species metabolize glutamate to produce GABA, GF mice exhibited altered N-methyl-D-aspartate (NMDA) receptor expression and increased glutamatergic activity and, reduction of GABA and enhancement of glutamate levels were reported in A $\beta$ PPswe-PS1dE9 mice [127-129]. SCFAs are capable of potently inhibit $A \beta$ aggregations in vitro, modulating maturation and function of microglia in the brain $[86,130]$ and butyric acid may provide therapeutic benefits for $A D$ through epigenetic mechanisms [131]. Primary bile acids, post-prandial secreted into the intestine, are further metabolized by the action of the gut microbiome into secondary bile acids that promote protein misfolding and impaired intra-cellular metabolism [132]. In addition, an alteration of bile acid profile in AD patients was associated with impairment of cognitive functions and changes in CSF markers of disease [133]. The microbial-derived metabolite trimethylamine $N$-oxide (TMAO) increases $\beta$-secretase activity and $\mathrm{A} \beta$ accumulation, and plasma TMAO levels were associated with deteriorative cognitive functions and AD pathology in APP/PS1 mice [134]. Gut bacteria such as E. coli, Salmonella and Citrobacter produce amyloids (curli, tau, $\mathrm{A} \beta, \alpha$-syn, and prion) that promote misfolding of $\mathrm{A} \beta$ oligomers and fibrils, contributing to $\mathrm{AD}$ pathology [135]. In addition, the activation of toll-like receptors 2/1 (TLR 2/1), cluster of differentiation 14 (CD14), and nuclear factor- $k B$ (NF-kB) promotes release of pro-inflammatory cytokines that by initiating immunogenic reactions contribute to neurodegeneration [136,137]. Bacterial endotoxins, found within the typical senile plaque lesions of the AD brains, exert a key role in the inflammatory processes associated with amyloidosis and AD [138]. Of note, increased pro-inflammatory and reduced anti-inflammatory cytokine blood levels were detected in patients with cognitive impairment and brain amyloidosis. The peripheral inflammatory state of patients was also associated with the increase of a pro-inflammatory Escherichia/Shigella and reduction of E. rectale bacteria abundance [139].

The link between gut microbiota and its dysbiosis as a risk factor for AD has supported by research of probiotics with anti-AD potential (Table 1) as well as by studies investigating the efficacy of fecal microbial transplantation (FMT) as a new therapeutic approach to treat dementia and AD. 
In A $\beta$ (1-42) injected rats, probiotics intake (Lactobacillus acidophilus, L. fermentum, Bifidobacterium lactis, and B. longum) for 8 weeks prevented learning and memory impairment and decreased the number and size of plaques [140]. In the same model, Lactobacillus acidophilus, Bifidobacterium bifidum and Bifidobacterium longum restored the hippocampus dependent spatial memory and synaptic plasticity damaged after $A \beta$ administration [141]. The administration of SLAB51, a novel formulation of lactic acid bacteria and bifido bacteria, to a triple-transgenic mouse model of AD (3xTg-AD) in the early stages of the disease counteracted cognitive decline and brain damage, modified intestinal microbiota, increased gut hormone concentration, influenced proteolysis, restoring impaired proteasome activities and modulating the autophagic flux [142]. SLAB51 treatment also reduced oxidative stress in AD mice brain via sirtuin 1-dependent mechanisms [143]. Attenuation of learning and memory deficits and recovery of $A \beta$ and Tau protein levels as well as cytokine levels in blood were reported after administration for four weeks of oligosaccharide extracted from Morinda officinalis to D-galactose evoked AD-like symptoms in rats [144]. The role of FMT in AD has been recently investigated in APPswe/PS1dE9 transgenic mouse and in a novel animal model of AD, the ADLPAPT mice characterized by three human transgenes, including amyloid precursor protein, presenilin-1, and tau which shows amyloid plaques, neurofibrillary tangles and reactive gliosis [145-147]. In an APPswe/PS1dE9 transgenic mouse model, FMT attenuated cognitive deficits and synaptic disfunction as well as reduced the neuroinflammatory markers [145]. In addition, FMT from WT mice into ADLPAPT mice ameliorated the formation of $A \beta$ plaques and tau, glial reactivity and cognitive impairment. Moreover, FMT, restored intestinal macrophage activity and inflammatory blood monocyte population altered in transgenic mice [147]. In AD patients, treatment with Lactobacillus acidophilus, Lactobacillus casei, Lactobacillus fermentum, and Bifidobacterium bifidum for three months improved cognitive functions and metabolic status as the probiotic treated group exhibited better Mini-Mental State Examination (MMSE) score and reduced markers of insulin metabolism, and serum levels of triglyceride and Very Low Density Lipoprotein (VLDL) [148]. Multispecies probiotic (Lactobacillus casei W56, Lactococcus lactis W19, Lactobacillus acidophilus W22, Bifidobacterium lactis W52, Lactobacillus paracasei W20, Lactobacillus plantarum W62, Bifidobacterium lactis W51, Bifidobacterium bifidum W23 and Lactobacillus salivarius W24) supplementation might modify gut bacteria composition and tryptophan metabolism of AD patients as an increase in Faecalibacterium prausnitzii with enhanced serum kynurenine concentrations were observed after 28 days of treatment [149]. Finally, a recent systematic review and meta-analysis of randomized clinical trials reported that evidence to support the clinical application of probiotics to improve cognitive function in humans with dementia is insufficient [150].

Table 1. Effect of probiotic supplementations in AD-like animal models and human patients.

\begin{tabular}{cccc}
\hline Model System & Probiotic Supplementation & Pathological Signature & Reference \\
\hline amyloid (1-42) injected rats & $\begin{array}{c}\text { L.acidophilus, L. fermentum, } \\
\text { B. lactis, and B. longum }\end{array}$ & $\begin{array}{c}\text { Prevented learning and memory impairment } \\
\text { and decreased the number and size of } \\
\text { plaques }\end{array}$ \\
\hline amyloid (1-42) injected rats & $\begin{array}{c}\text { L. acidophilus, B. bifidum and } \\
\text { B. longum }\end{array}$ & $\begin{array}{c}\text { Restored the hippocampus dependent spatial } \\
\text { memory and synaptic plasticity damaged }\end{array}$ \\
\hline 3xTg-AD transgenic mice & SLAB51 & $\begin{array}{c}\text { Counteracted cognitive decline and brain } \\
\text { damage, increased gut hormone } \\
\text { concentration, restored impaired proteasome } \\
\text { activities, modulated the autophagic flux and } \\
\text { reduced oxidative stress }\end{array}$ \\
\hline [142,143]
\end{tabular}


Table 1. Cont.

\begin{tabular}{|c|c|c|c|}
\hline Model System & Probiotic Supplementation & Pathological Signature & Reference \\
\hline AD patients & $\begin{array}{c}\text { L. acidophilus, L. casei, } \\
\text { L. fermentum, and B. bifidum }\end{array}$ & $\begin{array}{l}\text { Improved cognitive functions and metabolic } \\
\text { status, reduced markers of insulin } \\
\text { metabolism and serum levels of triglyceride } \\
\text { and VLDL }\end{array}$ & [148] \\
\hline AD patients & $\begin{array}{l}\text { L. casei W56, L. lactis W19, } \\
\text { L. acidophilus W22, } \\
\text { B. lactis W52, L. paracasei W20, } \\
\text { L. plantarum W62, } \\
\text { B. lactis W51, B. bifidum W23 } \\
\text { and L. salivarius W24 }\end{array}$ & Enhanced serum kynurenine concentrations & [149] \\
\hline
\end{tabular}

\section{Crosstalk between Gut Microbiota and eCB System}

The eCB system is widely distributed throughout the gut in health and disease and its involvement in gastrointestinal physiological and pathophysiological processes has been described [151,152]. As the microbiota is the main character in the intestinal tract, alterations in the gut microbiota composition might influence the eCB system signaling or they might influence each other while performing their role in the gut. Studies that were mainly focused on metabolic and obesity-related disorders have suggested that modulation of the eCBome is associated with changes in the gut bacterial community and, on the other hand, the modification of the gut microbiota by using probiotics, antibiotics or GF mice affected eCB signaling.

In a mouse model of diet-induced obesity (DIO), $\mathrm{CB}_{1}$ antagonist treatment increased Akkermansia muciniphila and decreased Lanchnospiraceae and Erysipelotrichaceae levels in the gut, attenuated inflammatory state and improved hyperglycemia and insulin resistance [153] while THC chronically administered in mice prevented DIO-induced increase of the Firmicutes:Bacteroidetes ratio [154]. Mice lacking the Napepld gene in their adipose tissue increased body-weight gain, insulin resistance, adipose tissue inflammation and altered lipid metabolism. In addition, the mutant mice exhibited lower levels of NAEs and a shift in gut microbiota composition as decreased levels of Lactobacillus and Allobaculum genera were observed [155]. Mice lacking the $M g l l$ gene were protected against high-fat diet (HFD)induced obesity, insulin resistance and hepatic steatosis [156] and exhibited significantly higher levels of Hydrogenoanaerobacterium, Roseburia, and Ruminococcus [157]. Reduction of colonic $\mathrm{CB}_{1}$ mRNA expression accompanied by increased expression of FAAH and reduction of AEA levels were reported in a genetic model of obesity, the $o b / o b$ mice, treated with prebiotics for 5 weeks. Still, $\mathrm{CB}_{1}$ expression levels were also reduced in lean wild-type mice after antibiotic treatment for 2 weeks [158]. Furthermore, mice treated for 7 days with non-absorbable-broad spectrum antibiotics selectively upregulated the expression of $\mathrm{CB}_{2}$ and exhibited altered microbiota profile as luminal counts of Lactobacillus and Enterobacteria were increased whereas the Clostridium and the Verrucobacteria groups were reduced [159]. Lactobacillus acidophilus treatment increased the expression of $\mathrm{CB}_{2}$ and induced analgesia in a rat model of chronic colonic hypersensitivity [160]. The cause-effect relationship between altered microbiome and modulation of eCBome were explored by assessing eCBome gene expression levels in small intestine of young and adult GF mice as well as in GF mice after microbiota re-introduction by FMT procedure [161]. In 13 weeks-old GF mice upregulation of $\mathrm{CB}_{1}$ and PPAR $\alpha$ and downregulation of GPR18 and GPR55 expression were reported, while genes encoding for NAE synthesis significantly increased in both 4- and 13-weeks-old GF mice. Notably, these modifications were, partially or completely, reverted after FMT from donor to age-matched GF mice [161]. Recently, in a mouse model of depression, the unpredictable chronic mild stress (UCMS) model, Chevalier and coworkers correlated the effect of gut microbiota on depressive-like behaviors in mice with modulation of the eCB system signaling. The authors reported that naive unstressed mice that underwent the FMT procedure from UCMS donors developed depressive behavioral symptoms and exhibited 
reduced neurogenesis in the hippocampus accompanied with a significant decrease of 2-AG levels in both UCMS donors and recipients. Of note, pharmacological modulation of 2-AG signaling, by using MAGL inhibitor, or complementation with a Lactobacillus probiotic strain normalized depressive symptoms and neurogenesis in recipient mice [162]. In a GI colonization model, mice inoculated with commensal fungus Candida albicans altered eCB levels in the brain and GI tract, increased anxiety-like behavior and basal levels of the stress hormone corticosterone. Treatment with an FAAH inhibitor, URB597, reverted both neuroendocrine phenotypes [22].

Antibiotic-induced experimental dysbiosis in mice caused social behavior alterations and depressive-like behavior, significant decreased brain-derived neurotrophic factor (BDNF) expression and increased phosphorylation, and hence increased sensitization, of TRPV1 in the hippocampus [21]. These alterations were counteracted by subsequent probiotic administration. In addition, intestinal levels of $N$-arachidonoylserotonin and $N$-oleoylserotonin, two members of the eCBome, decreased in dysbiotic mice and increased after probiotic treatment in the mouse jejunum [21].

Few human studies have been reported so far on the linking changes in gut microbiota composition with changes in eCB system mediators and proteins. In a randomized clinical trial including 60 obese people, OEA supplementation, for 8 weeks, significantly decreased carbohydrate intake and increased the abundance of Akkermansia muciniphila bacterium, one of the next-generation beneficial microbes, inversely associated with obesity and diabetes $[163,164]$. In addition, in a cohort consisting of 32 overweight or obese subjects, 3 months of daily supplementation with Akkermansia muciniphila exerted its beneficial effects in a way independent from the modulation of the plasmatic levels of 25 different eCBome-related lipids [165]. Akkermansia muciniphila supplementation prevented the reduction of 2-palmitoylglycerol (2-PG) levels in human patients and increased production of 2-PG, 2-oleoylglycerol (2-OG), and 2-AG in obese mice [165,166]. Recently, by using a multilevel mediation model that establish alpha diversity, within individual gut-microbial diversity, as predictor, serum and fecal levels of PEA as mediator, and anhedonia/amotivation as outcome, PEA was reported to mediate the association between gut-microbial diversity and anhedonia/amotivation in a longitudinal study performed on 786 volunteer twins [167]. Finally, in a heterogeneous human population of 195 healthy volunteers, changes in circulating levels of MAGs and NAEs were correlated with diet-induced changes in gut microbiota composition [168]. In particular, NAE levels were enhanced in elevated fat mass volunteers, while 2-MAGs were increased in individuals with predominant visceral body fat distribution. Subject that self-reported higher omega-3 fatty acid intakes exhibited higher level of omega-3 derived NAEs and 2-MAGs and, while several NAEs were positively associated with Peptostreptoccocaceae and Veillonellaceae families, 2-MAG levels were negatively associated with kermansiaceae [168].

\section{The eCBome as the "Hidden" Player between the Gut and the Brain in AD}

Studies most in the context of metabolic dysfunctions, already reviewed elsewhere [19,169], suggest cross-talk between the gut microbiome and the eCBome. However, the connection of the gut-brain axis and the eCBome in neurodegenerative diseases has never been deeply investigated but, considering the important role of these two systems in the physiopathology of the CNS, it is worth doing it. As already stated above, even if no specific data exist in the literature yet, we will try to elucidate some possible mechanisms that underline the communication between the gut-brain axis and the eCBome in the AD.

In the last decades the modulation of the $\mathrm{CCB}$ system has emerged as a potentially attractive therapeutic strategy for the treatment of AD (Figure 1), as reviewed in [17,18,170]. In particular, human studies have shown that $C_{2}$ receptors and $F A A H$ are overexpressed in neuritic plaque-associated glia analyzed in post-mortem AD brains [171], especially in perivascular microglial cells [172]. Moreover, the expression of $\mathrm{CB}_{2}$ and $\mathrm{FAAH}$ is related to the $A \beta$ deposition suggesting a possible regulatory role associated with the pathological alterations of $\mathrm{AD}$ induced in microglial cells. On the other hand, the role of $\mathrm{CB}_{1}$ is debating, 
but human studies have pointed out that $\mathrm{CB}_{1}$ activity is higher at earlier $\mathrm{AD}$ stages with a later decrease [173]. Furthermore, in an in vitro study, $\mathrm{CB}_{1}$ activation has revealed the beneficial neuroprotective effects reducing $A \beta$ deposition and tau phosphorylation [174]. The question is, how does the eCBome communicate with the microbiome gut-brain axis and what is the role of this interplay in the pathophysiology of the AD?

We consider two hypotheses to answer to this: neuroinflammation and obesity as risk factor for AD. Neuroinflammation is related to microbial translocation by a leaky gut barrier which in turn may affect the CNS through the VN and enteroendocrine signaling [175]. In this context, it is worth mentioning the well-established LPS translocation pathway and chronic inflammation in the CNS due to microglial activation that could be modulated by eCBs. In fact, AEA can induce gut permeability, causing a 'leaky' gut which in turn lead to the onset of metabolic endotoxemia releasing toxins, including LPS, to cross the epithelial barrier driving inflammatory signaling and affecting the CNS [20]. In particular, primarily by leading the release of pro-inflammatory cytokines and other neurotrophic factors from the mesenteric lymph nodes which albeit to BBB disruption, LPS favors the infiltration of leukocytes into the CNS and finally promotes the development of neuroinflammation state. Therefore, targeting the $\mathrm{eCB}$ system in the gut can modulate the integrity of intestinal barrier [176]. Furthermore, leaky gut and endotoxemia are characteristic features of obesity [177] that is considered a risk factor for AD. In recent years, the link between the obesity and the subsequent leptin and insulin impaired signals with the onset of the AD pathology have been studied [178]. In particular, the increased adipose tissue in obesity could trigger a blood flow decrease to brain, which lead ischemia in vulnerable areas, such as neurons in the hippocampal regions CA1, CA3, and CA4, that in turn could be one of the main cause of increased memory loss $[179,180]$. Moreover, the release of adipose tissue hormones, adipokines as leptin and other cytokines causes chronic inflammation in the periphery that may reach the CNS leading to neuroinflammation, reduction of brain white matter and impairment of neuronal connections [181,182]. Several studies supported the connection between leptin levels and AD pathophysiology [183] as leptin levels were found to be lower in $\mathrm{AD}$ patients than in healthy controls, suggesting a positive correlation with the reduction of AD risk [184]. Furthermore, chronic leptin administration improved memory functions and $A B$ clearance in a transgenic animal model of $A D$ [185]. Of note, leptin and eCBs are strictly correlated, as first demonstrated by Di Marzo et al. [186], showing that leptin inhibits the biosynthesis of eCBs in the hypothalamus in the appetite-related circuit via orexigenic mediators. Moreover, in mice leptin is able to decrease the release of eCBs by inhibiting voltage-gated calcium entry [187]. Therefore, it is likely to suggest that the interplay between eCBs and leptin is one of the not well-investigated mechanisms through which the gut-brain axis is regulated under pathological conditions, especially in the context of AD. As mentioned in the previous sections, elevated tissue levels of 2-AG in $\mathrm{Mgll}^{-/-}$mice are associated with resistance to the metabolic alterations induced by a HFD as they accumulated less fat and became less glucose intolerant and insulin resistant than WT mice following HFD [156] and changes in $\mathrm{Mgll}^{-/-}$mice microbiome have been reported to contribute to their obesity resistant phenotype [156,157]. In addition, pharmacological elevation of 2-AG levels with MAGL inhibitor prevented neuroinflammation and decreased neurodegeneration in different AD-like animal models [188,189]. Of note, deletion of MAGL in astrocytes attenuated LPS-induced neuroinflammation in mice and genetic MAGL inactivation in PS1/APP AD model reduced prostaglandin production, A $\beta$ levels and plaques $[190,191]$. This suggests that MAGL is a key modulator of gut microbiota composition, inflammation and amyloidosis and might be considered as a potential next-generation target whose deep investigation might provide new therapeutic strategy against $\mathrm{AD}$ etiology and its modifiable risk factors.

\section{Conclusions}

Although both the eCB system and the gut microbiota have individually emerged as molecular targets in the pathology of $\mathrm{AD}$ as they may counteract inflammatory, neurode- 
generative and cognitive aspects of the disease, research on the complex interactions of these systems in AD is still missing.

The overlapping roles of the eCB system and the microbiome in many diseases including dysmetabolism, obesity and neuropsychiatric disorders $[19,44]$ suggest that a novel approach such as modulating the microbiota via eCB system may provide new therapeutic perspectives for treating AD. In particular, therapeutic strategies derived by diets or prebiotic and probiotic supplementation that might promote and support the growth of bacteria synthetizing beneficial mediators, eCBs and eCB-like compounds included, acting as AD-modifying drugs should be examined. On the other hand, the potential beneficial role of increased levels of 2-AG and hence the activation of $\mathrm{CB}_{2}$ and other molecular targets belonging to the family of eCBome receptors mediating inflammation and gut microbiota composition and diversity should be clarified.

In conclusion, studies are now needed to provide answers to the question of whether or not the $\mathrm{eCB}$ system can be considered a bridge between gut microbiota and $\mathrm{AD}$ to be target for the development of applicable interventions for the treatment of the progress of neurodegenerative disorders.

Author Contributions: Conceptualization, T.B. and F.P.; writing-review and editing, T.B., A.L. and F.P. All authors have read and agreed to the published version of the manuscript.

Funding: This research received no external funding.

Institutional Review Board Statement: Not applicable.

Informed Consent Statement: Not applicable.

Data Availability Statement: Not applicable.

Conflicts of Interest: The authors declare no conflict of interest.

\section{References}

1. Alzheimer's Association. 2019 Alzheimer's Disease Facts and Figures. Alzheimer's Dement. 2019, 15, 321-387. [CrossRef]

2. Claesson, M.J.; Cusack, S.; O'Sullivan, O.; Greene-Diniz, R.; de Weerd, H.; Flannery, E.; Marchesi, J.R.; Falush, D.; Dinan, T.; Fitzgerald, G.; et al. Composition, Variability, and Temporal Stability of the Intestinal Microbiota of the Elderly. Proc. Natl. Acad. Sci. USA 2011, 108, 4586-4591. [CrossRef]

3. Westfall, S.; Lomis, N.; Kahouli, I.; Dia, S.Y.; Singh, S.P.; Prakash, S. Microbiome, Probiotics and Neurodegenerative Diseases: Deciphering the Gut Brain Axis. Cell Mol. Life Sci. 2017, 74, 3769-3787. [CrossRef] [PubMed]

4. Zhu, X.; Han, Y.; Du, J.; Liu, R.; Jin, K.; Yi, W. Microbiota-Gut-Brain Axis and the Central Nervous System. Oncotarget 2017, 8, 53829-53838. [CrossRef]

5. Yemula, N.; Dietrich, C.; Dostal, V.; Hornberger, M. Parkinson's Disease and the Gut: Symptoms, Nutrition, and Microbiota. J. Park. Dis. 2021, 2021. in press. [CrossRef]

6. Yue, Q.; Cai, M.; Xiao, B.; Zhan, Q.; Zeng, C. The Microbiota-Gut-Brain Axis and Epilepsy. Cell Mol. Neurobiol. 2021, 285, 1-15. [CrossRef]

7. Blacher, E.; Bashiardes, S.; Shapiro, H.; Rothschild, D.; Mor, U.; Dori-Bachash, M.; Kleimeyer, C.; Moresi, C.; Harnik, Y.; Zur, M.; et al. Potential Roles of Gut Microbiome and Metabolites in Modulating ALS in Mice. Nature 2019, 572, 474-480. [CrossRef]

8. Li, M.; Wang, F. Role of Intestinal Microbiota on Gut Homeostasis and Rheumatoid Arthritis. J. Immunol. Res. 2021, $2021,8167283$. [CrossRef]

9. Cunningham, A.L.; Stephens, J.W.; Harris, D.A. A Review on Gut Microbiota: A Central Factor in the Pathophysiology of Obesity. Lipids Health Dis. 2021, 20, 65. [CrossRef] [PubMed]

10. Javier-DesLoges, J.; McKay, R.R.; Swafford, A.D.; Sepich-Poore, G.D.; Knight, R.; Parsons, J.K. The Microbiome and Prostate Cancer. Prostate Cancer Prostatic Dis. 2021, 232, 1-6. [CrossRef]

11. Harach, T.; Marungruang, N.; Duthilleul, N.; Cheatham, V.; Mc Coy, K.D.; Frisoni, G.; Neher, J.J.; Fåk, F.; Jucker, M.; Lasser, T.; et al. Reduction of Abeta Amyloid Pathology in APPPS1 Transgenic Mice in the Absence of Gut Microbiota. Sci. Rep. 2017, 7, 41802. [CrossRef]

12. Vogt, N.M.; Kerby, R.L.; Dill-McFarland, K.A.; Harding, S.J.; Merluzzi, A.P.; Johnson, S.C.; Carlsson, C.M.; Asthana, S.; Zetterberg, H.; Blennow, K.; et al. Gut Microbiome Alterations in Alzheimer's Disease. Sci. Rep. 2017, 7, 13537. [CrossRef] [PubMed]

13. Cristino, L.; Bisogno, T.; Di Marzo, V. Cannabinoids and the Expanded Endocannabinoid System in Neurological Disorders. Nat. Rev. Neurol. 2020, 16, 9-29. [CrossRef]

14. DiPatrizio, N.V. Endocannabinoids and the Gut-Brain Control of Food Intake and Obesity. Nutrients 2021, 13, 1214. [CrossRef] [PubMed] 
15. Forteza, F.; Giorgini, G.; Raymond, F. Neurobiological Processes Induced by Aerobic Exercise through the Endocannabinoidome. Cells 2021, 10, 938. [CrossRef] [PubMed]

16. Rakotoarivelo, V.; Sihag, J.; Flamand, N. Role of the Endocannabinoid System in the Adipose Tissue with Focus on Energy Metabolism. Cells 2021, 10, 1279. [CrossRef] [PubMed]

17. Abate, G.; Uberti, D.; Tambaro, S. Potential and Limits of Cannabinoids in Alzheimer's Disease Therapy. Biology 2021, 10, 542. [CrossRef]

18. Berry, A.J.; Zubko, O.; Reeves, S.J.; Howard, R.J. Endocannabinoid System Alterations in Alzheimer's Disease: A Systematic Review of Human Studies. Brain Res. 2020, 1749, 147135. [CrossRef]

19. Iannotti, F.A.; Di Marzo, V. The Gut Microbiome, Endocannabinoids and Metabolic Disorders. J. Endocrinol. 2021, 248, R83-R97. [CrossRef]

20. Cani, P.D.; Plovier, H.; Van Hul, M.; Geurts, L.; Delzenne, N.M.; Druart, C.; Everard, A. Endocannabinoids-At the Crossroads between the Gut Microbiota and Host Metabolism. Nat. Rev. Endocrinol. 2016, 12, 133-143. [CrossRef]

21. Guida, F.; Turco, F.; Iannotta, M.; De Gregorio, D.; Palumbo, I.; Sarnelli, G.; Furiano, A.; Napolitano, F.; Boccella, S.; Luongo, L.; et al. Antibiotic-Induced Microbiota Perturbation Causes Gut Endocannabinoidome Changes, Hippocampal Neuroglial Reorganization and Depression in Mice. Brain Behav. Immun. 2018, 67, 230-245. [CrossRef]

22. Markey, L.; Hooper, A.; Melon, L.C.; Baglot, S.; Hill, M.N.; Maguire, J.; Kumamoto, C.A. Colonization with the Commensal Fungus Candida Albicans Perturbs the Gut-Brain Axis through Dysregulation of Endocannabinoid Signaling. Psychoneuroendocrinology 2020, 121, 104808. [CrossRef]

23. Di Marzo, V.; De Petrocellis, L.; Bisogno, T. The Biosynthesis, Fate and Pharmacological Properties of Endocannabinoids. Handb. Exp. Pharmacol. 2005, 168, 147-185. [CrossRef]

24. Tantimonaco, M.; Ceci, R.; Sabatini, S.; Catani, M.V.; Rossi, A.; Gasperi, V.; Maccarrone, M. Physical Activity and the Endocannabinoid System: An Overview. Cell Mol. Life Sci. 2014, 71, 2681-2698. [CrossRef] [PubMed]

25. Cadas, H.; Gaillet, S.; Beltramo, M.; Venance, L.; Piomelli, D. Biosynthesis of an Endogenous Cannabinoid Precursor in Neurons and Its Control by Calcium and CAMP. J. Neurosci. 1996, 16, 3934-3942. [CrossRef] [PubMed]

26. Kano, M.; Ohno-Shosaku, T.; Hashimotodani, Y.; Uchigashima, M.; Watanabe, M. Endocannabinoid-Mediated Control of Synaptic Transmission. Physiol. Rev. 2009, 89, 309-380. [CrossRef]

27. Di Marzo, V.; De Petrocellis, L.; Sepe, N.; Buono, A. Biosynthesis of Anandamide and Related Acylethanolamides in Mouse J774 Macrophages and N18 Neuroblastoma Cells. Biochem. J. 1996, 316, 977-984. [CrossRef]

28. Bisogno, T.; Howell, F.; Williams, G.; Minassi, A.; Cascio, M.G.; Ligresti, A.; Matias, I.; Schiano-Moriello, A.; Paul, P.; Williams, E.-J.; et al. Cloning of the First Sn1-DAG Lipases Points to the Spatial and Temporal Regulation of Endocannabinoid Signaling in the Brain. J. Cell Biol. 2003, 163, 463-468. [CrossRef]

29. Okamoto, Y.; Morishita, J.; Tsuboi, K.; Tonai, T.; Ueda, N. Molecular Characterization of a Phospholipase D Generating Anandamide and Its Congeners. J. Biol. Chem. 2004, 279, 5298-5305. [CrossRef]

30. Cravatt, B.F.; Giang, D.K.; Mayfield, S.P.; Boger, D.L.; Lerner, R.A.; Gilula, N.B. Molecular Characterization of an Enzyme That Degrades Neuromodulatory Fatty-Acid Amides. Nature 1996, 384, 83-87. [CrossRef]

31. Dinh, T.P.; Carpenter, D.; Leslie, F.M.; Freund, T.F.; Katona, I.; Sensi, S.L.; Kathuria, S.; Piomelli, D. Brain Monoglyceride Lipase Participating in Endocannabinoid Inactivation. Proc. Natl. Acad. Sci. USA 2002, 99, 10819-10824. [CrossRef] [PubMed]

32. Kreitzer, A.C.; Regehr, W.G. Retrograde Signaling by Endocannabinoids. Curr. Opin. Neurobiol. 2002, 12, 324-330. [CrossRef]

33. Castillo, P.E.; Younts, T.J.; Chávez, A.E.; Hashimotodani, Y. Endocannabinoid Signaling and Synaptic Function. Neuron 2012, 76, 70-81. [CrossRef]

34. Behl, T.; Kaur, G.; Bungau, S.; Jhanji, R.; Kumar, A.; Mehta, V.; Zengin, G.; Brata, R.; Hassan, S.S.; Fratila, O. Distinctive Evidence Involved in the Role of Endocannabinoid Signalling in Parkinson's Disease: A Perspective on Associated Therapeutic Interventions. Int. J. Mol. Sci. 2020, 21, 6235. [CrossRef] [PubMed]

35. Reddy, V.; Grogan, D.; Ahluwalia, M.; Salles, É.L.; Ahluwalia, P.; Khodadadi, H.; Alverson, K.; Nguyen, A.; Raju, S.P.; Gaur, P.; et al. Targeting the Endocannabinoid System: A Predictive, Preventive, and Personalized Medicine-Directed Approach to the Management of Brain Pathologies. EPMA J. 2020, 11, 217-250. [CrossRef]

36. Jones, É.; Vlachou, S. A Critical Review of the Role of the Cannabinoid Compounds $\Delta 9$-Tetrahydrocannabinol ( $\triangle 9$-THC) and Cannabidiol (CBD) and Their Combination in Multiple Sclerosis Treatment. Molecules 2020, 25, 4930. [CrossRef]

37. Leweke, F.M.; Mueller, J.K.; Lange, B.; Fritze, S.; Topor, C.E.; Koethe, D.; Rohleder, C. Role of the Endocannabinoid System in the Pathophysiology of Schizophrenia: Implications for Pharmacological Intervention. CNS Drugs 2018, 32, 605-619. [CrossRef]

38. Lutz, B.; Marsicano, G.; Maldonado, R.; Hillard, C.J. The Endocannabinoid System in Guarding against Fear, Anxiety and Stress. Nat. Rev. Neurosci. 2015, 16, 705-718. [CrossRef]

39. Di Marzo, V. New Approaches and Challenges to Targeting the Endocannabinoid System. Nat. Rev. Drug Discov. 2018, 17, 623-639. [CrossRef]

40. Watkins, B.A. Diet, Endocannabinoids, and Health. Nutr. Res. 2019, 70, 32-39. [CrossRef]

41. Ashton, J.C.; Glass, M. The Cannabinoid CB2 Receptor as a Target for Inflammation-Dependent Neurodegeneration. Curr. Neuropharmacol. 2007, 5, 73-80. [CrossRef]

42. Arturo, I.F.; Fabiana, P. Endocannabinoidome. In eLS; John Wiley \& Sons, Ltd.: Chichester, UK, 2018; pp. 1-10, ISBN 978-0-470-01590-2. 
43. Fezza, F.; Bari, M.; Florio, R.; Talamonti, E.; Feole, M.; Maccarrone, M. Endocannabinoids, Related Compounds and Their Metabolic Routes. Molecules 2014, 19, 17078-17106. [CrossRef]

44. Di Marzo, V. The Endocannabinoidome as a Substrate for Noneuphoric Phytocannabinoid Action and Gut Microbiome Dysfunction in Neuropsychiatric Disorders. Dialogues Clin. Neurosci. 2020, 22, 259-269. [CrossRef] [PubMed]

45. Lacroix, S.; Pechereau, F.; Leblanc, N.; Boubertakh, B.; Houde, A.; Martin, C.; Flamand, N.; Silvestri, C.; Raymond, F.; Di Marzo, V.; et al. Rapid and Concomitant Gut Microbiota and Endocannabinoidome Response to Diet-Induced Obesity in Mice. $m S y s t e m s$ 2019, 4, e00407-19. [CrossRef]

46. Ursell, L.K.; Metcalf, J.L.; Parfrey, L.W.; Knight, R. Defining the Human Microbiome. Nutr. Rev. 2012, 70, S38-S44. [CrossRef] [PubMed]

47. D'Argenio, V.; Salvatore, F. The Role of the Gut Microbiome in the Healthy Adult Status. Clin. Chim. Acta 2015, 451, 97-102. [CrossRef] [PubMed]

48. Dinan, T.G.; Stilling, R.M.; Stanton, C.; Cryan, J.F. Collective Unconscious: How Gut Microbes Shape Human Behavior. J. Psychiatr. Res. 2015, 63, 1-9. [CrossRef]

49. Donia, M.S.; Cimermancic, P.; Schulze, C.J.; Wieland Brown, L.C.; Martin, J.; Mitreva, M.; Clardy, J.; Linington, R.G.; Fischbach, M.A. A Systematic Analysis of Biosynthetic Gene Clusters in the Human Microbiome Reveals a Common Family of Antibiotics. Cell 2014, 158, 1402-1414. [CrossRef]

50. Gill, S.R.; Pop, M.; DeBoy, R.T.; Eckburg, P.B.; Turnbaugh, P.J.; Samuel, B.S.; Gordon, J.I.; Relman, D.A.; Fraser-Liggett, C.M.; Nelson, K.E. Metagenomic Analysis of the Human Distal Gut Microbiome. Science 2006, 312, 1355-1359. [CrossRef]

51. Nicholson, J.K.; Holmes, E.; Wilson, I.D. Gut Microorganisms, Mammalian Metabolism and Personalized Health Care. Nat. Rev. Microbiol. 2005, 3, 431-438. [CrossRef]

52. Qin, J.; Li, R.; Raes, J.; Arumugam, M.; Burgdorf, K.S.; Manichanh, C.; Nielsen, T.; Pons, N.; Levenez, F.; Yamada, T.; et al. A Human Gut Microbial Gene Catalogue Established by Metagenomic Sequencing. Nature 2010, 464, 59-65. [CrossRef]

53. Eckburg, P.B.; Bik, E.M.; Bernstein, C.N.; Purdom, E.; Dethlefsen, L.; Sargent, M.; Gill, S.R.; Nelson, K.E.; Relman, D.A. Diversity of the Human Intestinal Microbial Flora. Science 2005, 308, 1635-1638. [CrossRef] [PubMed]

54. Nadia Gaci, G.B.; Toole, J.-F.; Brugegrave, O. Archaea and the Human Gut: New Beginning of an Old Story. World J. Gastroenterol. 2014, 20, 16062-16078. [CrossRef] [PubMed]

55. Lankelma, J.M.; Nieuwdorp, M.; de Vos, W.M.; Wiersinga, W.J. The Gut Microbiota in Internal Medicine: Implications for Health and Disease. Neth. J. Med. 2015, 73, 61-68. [PubMed]

56. Scarpellini, E.; Ianiro, G.; Attili, F.; Bassanelli, C.; De Santis, A.; Gasbarrini, A. The Human Gut Microbiota and Virome: Potential Therapeutic Implications. Dig. Liver Dis. 2015, 47, 1007-1012. [CrossRef] [PubMed]

57. Williamson, L.L.; McKenney, E.A.; Holzknecht, Z.E.; Belliveau, C.; Rawls, J.F.; Poulton, S.; Parker, W.; Bilbo, S.D. Got Worms? Perinatal Exposure to Helminths Prevents Persistent Immune Sensitization and Cognitive Dysfunction Induced by Early-Life Infection. Brain Behav. Immun. 2016, 51, 14-28. [CrossRef] [PubMed]

58. Li, J.; Jia, H.; Cai, X.; Zhong, H.; Feng, Q.; Sunagawa, S.; Arumugam, M.; Kultima, J.R.; Prifti, E.; Nielsen, T.; et al. An Integrated Catalog of Reference Genes in the Human Gut Microbiome. Nat. Biotechnol. 2014, 32, 834-841. [CrossRef] [PubMed]

59. Hugon, P.; Dufour, J.-C.; Colson, P.; Fournier, P.-E.; Sallah, K.; Raoult, D. A Comprehensive Repertoire of Prokaryotic Species Identified in Human Beings. Lancet Infect. Dis. 2015, 15, 1211-1219. [CrossRef]

60. Bilen, M.; Dufour, J.-C.; Lagier, J.-C.; Cadoret, F.; Daoud, Z.; Dubourg, G.; Raoult, D. The Contribution of Culturomics to the Repertoire of Isolated Human Bacterial and Archaeal Species. Microbiome 2018, 6, 94. [CrossRef] [PubMed]

61. Lloyd-Price, J.; Mahurkar, A.; Rahnavard, G.; Crabtree, J.; Orvis, J.; Hall, A.B.; Brady, A.; Creasy, H.H.; McCracken, C.; Giglio, M.G.; et al. Erratum: Strains, Functions and Dynamics in the Expanded Human Microbiome Project. Nature 2017, 551,256 [CrossRef]

62. Mosca, A.; Leclerc, M.; Hugot, J.P. Gut Microbiota Diversity and Human Diseases: Should We Reintroduce Key Predators in Our Ecosystem? Front. Microbiol. 2016, 7, 455. [CrossRef] [PubMed]

63. Pasolli, E.; Asnicar, F.; Manara, S.; Zolfo, M.; Karcher, N.; Armanini, F.; Beghini, F.; Manghi, P.; Tett, A.; Ghensi, P.; et al. Extensive Unexplored Human Microbiome Diversity Revealed by Over 150,000 Genomes from Metagenomes Spanning Age, Geography, and Lifestyle. Cell 2019, 176, 649-662.e20. [CrossRef] [PubMed]

64. Bokulich, N.A.; Chung, J.; Battaglia, T.; Henderson, N.; Jay, M.; Li, H.; Lieber, A.D.; Wu, F.; Perez-Perez, G.I.; Chen, Y.; et al. Antibiotics, Birth Mode, and Diet Shape Microbiome Maturation during Early Life. Sci. Transl. Med. 2016, 8, 343ra82. [CrossRef]

65. Chu, D.M.; Ma, J.; Prince, A.L.; Antony, K.M.; Seferovic, M.D.; Aagaard, K.M. Maturation of the Infant Microbiome Community Structure and Function across Multiple Body Sites and in Relation to Mode of Delivery. Nat. Med. 2017, 23, 314-326. [CrossRef]

66. Yassour, M.; Vatanen, T.; Siljander, H.; Hämäläinen, A.-M.; Härkönen, T.; Ryhänen, S.J.; Franzosa, E.A.; Vlamakis, H.; Huttenhower C.; Gevers, D.; et al. Natural History of the Infant Gut Microbiome and Impact of Antibiotic Treatment on Bacterial Strain Diversity and Stability. Sci. Transl. Med. 2016, 8,343ra81. [CrossRef]

67. Koenig, J.E.; Spor, A.; Scalfone, N.; Fricker, A.D.; Stombaugh, J.; Knight, R.; Angenent, L.T.; Ley, R.E. Succession of Microbial Consortia in the Developing Infant Gut Microbiome. Proc. Natl. Acad. Sci. USA 2011, 108, 4578-4585. [CrossRef]

68. Palmer, C.; Bik, E.M.; DiGiulio, D.B.; Relman, D.A.; Brown, P.O. Development of the Human Infant Intestinal Microbiota. PLoS Biol. 2007, 5, e177. [CrossRef] 
69. Yatsunenko, T.; Rey, F.E.; Manary, M.J.; Trehan, I.; Dominguez-Bello, M.G.; Contreras, M.; Magris, M.; Hidalgo, G.; Baldassano, R.N.; Anokhin, A.P.; et al. Human Gut Microbiome Viewed across Age and Geography. Nature 2012, 486, 222-227. [CrossRef]

70. Hollister, E.B.; Riehle, K.; Luna, R.A.; Weidler, E.M.; Rubio-Gonzales, M.; Mistretta, T.-A.; Raza, S.; Doddapaneni, H.V.; Metcalf, G.A.; Muzny, D.M.; et al. Structure and Function of the Healthy Pre-Adolescent Pediatric Gut Microbiome. Microbiome 2015, 3, 36. [CrossRef]

71. Vauzour, D.; Camprubi-Robles, M.; Miquel-Kergoat, S.; Andres-Lacueva, C.; Bánáti, D.; Barberger-Gateau, P.; Bowman, G.L.; Caberlotto, L.; Clarke, R.; Hogervorst, E.; et al. Nutrition for the Ageing Brain: Towards Evidence for an Optimal Diet. Ageing Res. Rev. 2017, 35, 222-240. [CrossRef] [PubMed]

72. Claesson, M.J.; Jeffery, I.B.; Conde, S.; Power, S.E.; O'Connor, E.M.; Cusack, S.; Harris, H.M.B.; Coakley, M.; Lakshminarayanan, B.; O'Sullivan, O.; et al. Gut Microbiota Composition Correlates with Diet and Health in the Elderly. Nature 2012, 488, 178-184. [CrossRef] [PubMed]

73. Jackson, M.A.; Jackson, M.; Jeffery, I.B.; Beaumont, M.; Bell, J.T.; Clark, A.G.; Ley, R.E.; O’Toole, P.W.; Spector, T.D.; Steves, C.J. Signatures of Early Frailty in the Gut Microbiota. Genome Med. 2016, 8, 8. [CrossRef] [PubMed]

74. Scott, K.A.; Ida, M.; Peterson, V.L.; Prenderville, J.A.; Moloney, G.M.; Izumo, T.; Murphy, K.; Murphy, A.; Ross, R.P.; Stanton, C.; et al. Revisiting Metchnikoff: Age-Related Alterations in Microbiota-Gut-Brain Axis in the Mouse. Brain Behav. Immun. 2017, 65, 20-32. [CrossRef] [PubMed]

75. Van Tongeren, S.P.; Slaets, J.P.J.; Harmsen, H.J.M.; Welling, G.W. Fecal Microbiota Composition and Frailty. Appl. Environ. Microbiol. 2005, 71, 6438-6442. [CrossRef]

76. Biagi, E.; Franceschi, C.; Rampelli, S.; Severgnini, M.; Ostan, R.; Turroni, S.; Consolandi, C.; Quercia, S.; Scurti, M.; Monti, D.; et al. Gut Microbiota and Extreme Longevity. Curr. Biol. 2016, 26, 1480-1485. [CrossRef] [PubMed]

77. Van der Lugt, B.; Rusli, F.; Lute, C.; Lamprakis, A.; Salazar, E.; Boekschoten, M.V.; Hooiveld, G.J.; Müller, M.; Vervoort, J.; Kersten, S.; et al. Integrative Analysis of Gut Microbiota Composition, Host Colonic Gene Expression and Intraluminal Metabolites in Aging C57BL/6J Mice. Aging 2018, 10, 930-950. [CrossRef] [PubMed]

78. Mayer, E.A. Gut Feelings: The Emerging Biology of Gut-Brain Communication. Nat. Rev. Neurosci. 2011, 12, 453-466. [CrossRef]

79. Collins, S.M.; Surette, M.; Bercik, P. The Interplay between the Intestinal Microbiota and the Brain. Nat. Rev. Microbiol. 2012, 10, 735-742. [CrossRef]

80. Carabotti, M.; Scirocco, A.; Maselli, M.A.; Severi, C. The Gut-Brain Axis: Interactions between Enteric Microbiota, Central and Enteric Nervous Systems. Ann. Gastroenterol. 2015, 28, 203-209. [PubMed]

81. Bonaz, B.; Bazin, T.; Pellissier, S. The Vagus Nerve at the Interface of the Microbiota-Gut-Brain Axis. Front. Neurosci. 2018, 12, 49. [CrossRef]

82. Doifode, T.; Giridharan, V.V.; Generoso, J.S.; Bhatti, G.; Collodel, A.; Schulz, P.E.; Forlenza, O.V.; Barichello, T. The Impact of the Microbiota-Gut-Brain Axis on Alzheimer's Disease Pathophysiology. Pharmacol. Res. 2021, 164, 105314. [CrossRef]

83. Mayer, E.A.; Tillisch, K.; Gupta, A. Gut/Brain Axis and the Microbiota. J. Clin. Investig. 2015, 125, 926-938. [CrossRef] [PubMed]

84. Cryan, J.F.; O'Riordan, K.J.; Sandhu, K.; Peterson, V.; Dinan, T.G. The Gut Microbiome in Neurological Disorders. Lancet Neurol. 2020, 19, 179-194. [CrossRef]

85. Hosoi, T.; Okuma, Y.; Nomura, Y. Electrical Stimulation of Afferent Vagus Nerve Induces IL- $1 \beta$ Expression in the Brain and Activates HPA Axis. Am. J. Physiol. Regul. Integr. Comp. Physiol. 2000, 279, R141-R147. [CrossRef] [PubMed]

86. Erny, D.; Hrabě de Angelis, A.L.; Jaitin, D.; Wieghofer, P.; Staszewski, O.; David, E.; Keren-Shaul, H.; Mahlakoiv, T.; Jakobshagen, K.; Buch, T.; et al. Host Microbiota Constantly Control Maturation and Function of Microglia in the CNS. Nat. Neurosci. 2015, 18, 965-977. [CrossRef] [PubMed]

87. D'Mello, C.; Le, T.; Swain, M.G. Cerebral Microglia Recruit Monocytes into the Brain in Response to Tumor Necrosis Factor $\alpha$ Signaling during Peripheral Organ Inflammation. J. Neurosci. 2009, 29, 2089-2102. [CrossRef]

88. D’Mello, C.; Ronaghan, N.; Zaheer, R.; Dicay, M.; Le, T.; MacNaughton, W.K.; Surrette, M.G.; Swain, M.G. Probiotics Improve Inflammation-Associated Sickness Behavior by Altering Communication between the Peripheral Immune System and the Brain. J. Neurosci. 2015, 35, 10821-10830. [CrossRef]

89. Cryan, J.F.; O’Riordan, K.J.; Cowan, C.S.M.; Sandhu, K.V.; Bastiaanssen, T.F.S.; Boehme, M.; Codagnone, M.G.; Cussotto, S.; Fulling, C.; Golubeva, A.V.; et al. The Microbiota-Gut-Brain Axis. Physiol. Rev. 2019, 99, 1877-2013. [CrossRef]

90. Reigstad, C.S.; Salmonson, C.E.; Iii, J.F.R.; Szurszewski, J.H.; Linden, D.R.; Sonnenburg, J.L.; Farrugia, G.; Kashyap, P.C. Gut Microbes Promote Colonic Serotonin Production through an Effect of Short-Chain Fatty Acids on Enterochromaffin Cells. FASEB J. 2015, 29, 1395-1403. [CrossRef]

91. Yano, J.M.; Yu, K.; Donaldson, G.P.; Shastri, G.G.; Ann, P.; Ma, L.; Nagler, C.R.; Ismagilov, R.F.; Mazmanian, S.K.; Hsiao, E.Y. Indigenous Bacteria from the Gut Microbiota Regulate Host Serotonin Biosynthesis. Cell 2015, 161, 264-276. [CrossRef]

92. Donovan, M.H.; Tecott, L.H. Serotonin and the Regulation of Mammalian Energy Balance. Front. Neurosci. 2013, 7, 36. [CrossRef]

93. O'Mahony, S.M.; Clarke, G.; Borre, Y.E.; Dinan, T.G.; Cryan, J.F. Serotonin, Tryptophan Metabolism and the Brain-Gut-Microbiome Axis. Behav. Brain Res. 2015, 277, 32-48. [CrossRef]

94. Cervenka, I.; Agudelo, L.Z.; Ruas, J.L. Kynurenines: Tryptophan's Metabolites in Exercise, Inflammation, and Mental Health. Science 2017, 357, aaf9794. [CrossRef] [PubMed]

95. Gill, P.A.; van Zelm, M.C.; Muir, J.G.; Gibson, P.R. Review Article: Short Chain Fatty Acids as Potential Therapeutic Agents in Human Gastrointestinal and Inflammatory Disorders. Aliment. Pharmacol. Ther. 2018, 48, 15-34. [CrossRef] [PubMed] 
96. Pluznick, J.L. Microbial Short-Chain Fatty Acids and Blood Pressure Regulation. Curr. Hypertens. Rep. 2017, 19, 25. [CrossRef]

97. Erny, D.; de Angelis, A.L.H.; Prinz, M. Communicating Systems in the Body: How Microbiota and Microglia Cooperate. Immunology 2017, 150, 7-15. [CrossRef] [PubMed]

98. Liu, S.; Li, E.; Sun, Z.; Fu, D.; Duan, G.; Jiang, M.; Yu, Y.; Mei, L.; Yang, P.; Tang, Y.; et al. Altered Gut Microbiota and Short Chain Fatty Acids in Chinese Children with Autism Spectrum Disorder. Sci. Rep. 2019, 9, 287. [CrossRef] [PubMed]

99. Zhang, L.; Wang, Y.; Xiayu, X.; Shi, C.; Chen, W.; Song, N.; Fu, X.; Zhou, R.; Xu, Y.-F.; Huang, L.; et al. Altered Gut Microbiota in a Mouse Model of Alzheimer's Disease. J. Alzheimer's Dis. 2017, 60, 1241-1257. [CrossRef]

100. Macfarlane, S.; Macfarlane, G.T. Regulation of Short-Chain Fatty Acid Production. Proc. Nutr. Soc. 2003, 62, 67-72. [CrossRef]

101. Wang, Y.; Wang, Z.; Wang, Y.; Li, F.; Jia, J.; Song, X.; Qin, S.; Wang, R.; Jin, F.; Kitazato, K.; et al. The Gut-Microglia Connection: Implications for Central Nervous System Diseases. Front. Immunol. 2018, 9, 2325. [CrossRef]

102. Hoyles, L.; Snelling, T.; Umlai, U.-K.; Nicholson, J.K.; Carding, S.R.; Glen, R.C.; McArthur, S. Microbiome-Host Systems Interactions: Protective Effects of Propionate upon the Blood-Brain Barrier. Microbiome 2018, 6, 55. [CrossRef]

103. Figueira, J.; Jonsson, P.; Nordin Adolfsson, A.; Adolfsson, R.; Nyberg, L.; Öhman, A. NMR Analysis of the Human Saliva Metabolome Distinguishes Dementia Patients from Matched Controls. Mol. Biosyst. 2016, 12, 2562-2571. [CrossRef]

104. Yilmaz, A.; Geddes, T.; Han, B.; Bahado-Singh, R.O.; Wilson, G.D.; Imam, K.; Maddens, M.; Graham, S.F. Diagnostic Biomarkers of Alzheimer's Disease as Identified in Saliva Using 1H NMR-Based Metabolomics. J. Alzheimer's Dis. 2017, 58, 355-359. [CrossRef]

105. Querfurth, H.W.; LaFerla, F.M. Alzheimer's Disease. N. Engl. J. Med. 2010, 362, 329-344. [CrossRef]

106. Sanchez-Mut, J.V.; Gräff, J. Epigenetic Alterations in Alzheimer's Disease. Front. Behav. Neurosci. 2015, 9, 347. [CrossRef]

107. Zhao, Y.; Zhao, B. Oxidative Stress and the Pathogenesis of Alzheimer's Disease. Oxid. Med. Cell Longev. 2013, $2013,316523$. [CrossRef]

108. Fasae, K.D.; Abolaji, A.O.; Faloye, T.R.; Odunsi, A.Y.; Oyetayo, B.O.; Enya, J.I.; Rotimi, J.A.; Akinyemi, R.O.; Whitworth, A.J.; Aschner, M. Metallobiology and Therapeutic Chelation of Biometals (Copper, Zinc and Iron) in Alzheimer's Disease: Limitations, and Current and Future Perspectives. J. Trace Elem. Med. Biol. 2021, 67, 126779. [CrossRef] [PubMed]

109. Swerdlow, R.H. Mitochondria and Mitochondrial Cascades in Alzheimer's Disease. J. Alzheimer's Dis. 2018, 62, 1403-1416. [CrossRef]

110. Dominy, S.S.; Lynch, C.; Ermini, F.; Benedyk, M.; Marczyk, A.; Konradi, A.; Nguyen, M.; Haditsch, U.; Raha, D.; Griffin, C.; et al. Porphyromonas Gingivalis in Alzheimer's Disease Brains: Evidence for Disease Causation and Treatment with Small-Molecule Inhibitors. Sci. Adv. 2019, 5, eaau3333. [CrossRef] [PubMed]

111. Ryder, M.I. Porphyromonas Gingivalis and Alzheimer Disease: Recent Findings and Potential Therapies. J. Periodontol. 2020, 91 (Suppl. S1), S45-S49. [CrossRef] [PubMed]

112. Zhu, S.; Jiang, Y.; Xu, K.; Cui, M.; Ye, W.; Zhao, G.; Jin, L.; Chen, X. The Progress of Gut Microbiome Research Related to Brain Disorders. J. Neuroinflamm. 2020, 17, 25. [CrossRef]

113. Komaroff, A.L. The Microbiome and Risk for Obesity and Diabetes. JAMA 2017, 317, 355-356. [CrossRef]

114. Barlow, G.M.; Yu, A.; Mathur, R. Role of the Gut Microbiome in Obesity and Diabetes Mellitus. Nutr. Clin. Pract. 2015, 30, 787-797. [CrossRef]

115. Aldars-García, L.; Chaparro, M.; Gisbert, J.P. Systematic Review: The Gut Microbiome and Its Potential Clinical Application in Inflammatory Bowel Disease. Microorganisms 2021, 9, 977. [CrossRef]

116. Chen, C.-H.; Lin, C.-L.; Kao, C.-H. Irritable Bowel Syndrome Is Associated with an Increased Risk of Dementia: A Nationwide Population-Based Study. PLoS ONE 2016, 11, e0144589. [CrossRef]

117. Alkasir, R.; Li, J.; Li, X.; Jin, M.; Zhu, B. Human Gut Microbiota: The Links with Dementia Development. Protein Cell 2017, 8, 90-102. [CrossRef]

118. Fu, P.; Gao, M.; Yung, K.K.L. Association of Intestinal Disorders with Parkinson's Disease and Alzheimer's Disease: A Systematic Review and Meta-Analysis. ACS Chem. Neurosci. 2020, 11, 395-405. [CrossRef]

119. Lyte, M. Microbial Endocrinology: Host-Microbiota Neuroendocrine Interactions Influencing Brain and Behavior. Gut Microbes 2014, 5, 381-389. [CrossRef] [PubMed]

120. Wall, R.; Cryan, J.F.; Ross, R.P.; Fitzgerald, G.F.; Dinan, T.G.; Stanton, C. Bacterial Neuroactive Compounds Produced by Psychobiotics. Adv. Exp. Med. Biol. 2014, 817, 221-239. [CrossRef] [PubMed]

121. Pistollato, F.; Sumalla Cano, S.; Elio, I.; Masias Vergara, M.; Giampieri, F.; Battino, M. Role of Gut Microbiota and Nutrients in Amyloid Formation and Pathogenesis of Alzheimer Disease. Nutr. Rev. 2016, 74, 624-634. [CrossRef] [PubMed]

122. Strandwitz, P. Neurotransmitter Modulation by the Gut Microbiota. Brain Res. 2018, 1693, 128-133. [CrossRef]

123. Forsythe, P.; Kunze, W.A. Voices from within: Gut Microbes and the CNS. Cell Mol. Life Sci. 2013, 70, 55-69. [CrossRef]

124. Velazquez, R.; Ferreira, E.; Knowles, S.; Fux, C.; Rodin, A.; Winslow, W.; Oddo, S. Lifelong Choline Supplementation Ameliorates Alzheimer's Disease Pathology and Associated Cognitive Deficits by Attenuating Microglia Activation. Aging Cell 2019, 18, e13037. [CrossRef]

125. Montoya, A.; Elgueta, D.; Campos, J.; Chovar, O.; Falcón, P.; Matus, S.; Alfaro, I.; Bono, M.R.; Pacheco, R. Dopamine Receptor D3 Signalling in Astrocytes Promotes Neuroinflammation. J. Neuroinflamm. 2019, 16, 258. [CrossRef]

126. Qian, X.-H.; Song, X.-X.; Liu, X.-L.; Chen, S.; Tang, H.-D. Inflammatory Pathways in Alzheimer's Disease Mediated by Gut Microbiota. Ageing Res. Rev. 2021, 68, 101317. [CrossRef] 
127. Neufeld, K.M.; Kang, N.; Bienenstock, J.; Foster, J.A. Reduced Anxiety-like Behavior and Central Neurochemical Change in Germ-Free Mice. Neurogastroenterol. Motil. 2011, 23, 255-264.e119. [CrossRef] [PubMed]

128. Tiwari, V.; Patel, A.B. Impaired Glutamatergic and GABAergic Function at Early Age in A $\beta P P s w e-P S 1 d E 9$ Mice: Implications for Alzheimer's Disease. J. Alzheimer's Dis. 2012, 28, 765-769. [CrossRef] [PubMed]

129. Mancuso, C.; Santangelo, R. Alzheimer's Disease and Gut Microbiota Modifications: The Long Way between Preclinical Studies and Clinical Evidence. Pharmacol. Res. 2018, 129, 329-336. [CrossRef]

130. Ho, L.; Ono, K.; Tsuji, M.; Mazzola, P.; Singh, R.; Pasinetti, G.M. Protective Roles of Intestinal Microbiota Derived Short Chain Fatty Acids in Alzheimer's Disease-Type Beta-Amyloid Neuropathological Mechanisms. Expert Rev. Neurother. 2018, 18, 83-90. [CrossRef] [PubMed]

131. Martins, I.J.; Fernando, W.M.A.D.B. High Fibre Diets and Alzheimer's Disease. Food Nutr. Sci. 2014, 5, 410-424. [CrossRef]

132. Merritt, M.E.; Donaldson, J.R. Effect of Bile Salts on the DNA and Membrane Integrity of Enteric Bacteria. J. Med. Microbiol. 2009, 58, 1533-1541. [CrossRef]

133. MahmoudianDehkordi, S.; Arnold, M.; Nho, K.; Ahmad, S.; Jia, W.; Xie, G.; Louie, G.; Kueider-Paisley, A.; Moseley, M.A.; Thompson, J.W.; et al. Altered Bile Acid Profile Associates with Cognitive Impairment in Alzheimer's Disease-An Emerging Role for Gut Microbiome. Alzheimer's Dement. 2019, 15, 76-92. [CrossRef]

134. Gao, Q.; Wang, Y.; Wang, X.; Fu, S.; Zhang, X.; Wang, R.-T.; Zhang, X. Decreased Levels of Circulating Trimethylamine N-Oxide Alleviate Cognitive and Pathological Deterioration in Transgenic Mice: A Potential Therapeutic Approach for Alzheimer's Disease. Aging 2019, 11, 8642-8663. [CrossRef] [PubMed]

135. Zhou, Y.; Smith, D.; Leong, B.J.; Brännström, K.; Almqvist, F.; Chapman, M.R. Promiscuous Cross-Seeding between Bacterial Amyloids Promotes Interspecies Biofilms. J. Biol. Chem. 2012, 287, 35092-35103. [CrossRef]

136. Friedland, R.P. Mechanisms of Molecular Mimicry Involving the Microbiota in Neurodegeneration. J. Alzheimer's Dis. 2015, 45, 349-362. [CrossRef] [PubMed]

137. Cerovic, M.; Forloni, G.; Balducci, C. Neuroinflammation and the Gut Microbiota: Possible Alternative Therapeutic Targets to Counteract Alzheimer's Disease? Front. Aging Neurosci. 2019, 11, 284. [CrossRef]

138. Asti, A.; Gioglio, L. Can a Bacterial Endotoxin Be a Key Factor in the Kinetics of Amyloid Fibril Formation? J. Alzheimer's Dis. 2014, 39, 169-179. [CrossRef] [PubMed]

139. Cattaneo, A.; Cattane, N.; Galluzzi, S.; Provasi, S.; Lopizzo, N.; Festari, C.; Ferrari, C.; Guerra, U.P.; Paghera, B.; Muscio, C.; et al. Association of Brain Amyloidosis with Pro-Inflammatory Gut Bacterial Taxa and Peripheral Inflammation Markers in Cognitively Impaired Elderly. Neurobiol. Aging 2017, 49, 60-68. [CrossRef] [PubMed]

140. Athari Nik Azm, S.; Djazayeri, A.; Safa, M.; Azami, K.; Ahmadvand, B.; Sabbaghziarani, F.; Sharifzadeh, M.; Vafa, M. Lactobacilli and Bifidobacteria Ameliorate Memory and Learning Deficits and Oxidative Stress in $\beta$-Amyloid (1-42) Injected Rats. Appl. Physiol. Nutr. Metab. 2018, 43, 718-726. [CrossRef] [PubMed]

141. Rezaei Asl, Z.; Sepehri, G.; Salami, M. Probiotic Treatment Improves the Impaired Spatial Cognitive Performance and Restores Synaptic Plasticity in an Animal Model of Alzheimer's Disease. Behav. Brain Res. 2019, 376, 112183. [CrossRef]

142. Bonfili, L.; Cecarini, V.; Berardi, S.; Scarpona, S.; Suchodolski, J.S.; Nasuti, C.; Fiorini, D.; Boarelli, M.C.; Rossi, G.; Eleuteri, A.M. Microbiota Modulation Counteracts Alzheimer's Disease Progression Influencing Neuronal Proteolysis and Gut Hormones Plasma Levels. Sci. Rep. 2017, 7, 2426. [CrossRef]

143. Bonfili, L.; Cecarini, V.; Cuccioloni, M.; Angeletti, M.; Berardi, S.; Scarpona, S.; Rossi, G.; Eleuteri, A.M. SLAB51 Probiotic Formulation Activates SIRT1 Pathway Promoting Antioxidant and Neuroprotective Effects in an AD Mouse Model. Mol. Neurobiol. 2018, 55, 7987-8000. [CrossRef] [PubMed]

144. Chen, D.; Yang, X.; Yang, J.; Lai, G.; Yong, T.; Tang, X.; Shuai, O.; Zhou, G.; Xie, Y.; Wu, Q. Prebiotic Effect of Fructooligosaccharides from Morinda Officinalis on Alzheimer's Disease in Rodent Models by Targeting the Microbiota-Gut-Brain Axis. Front. Aging Neurosci. 2017, 9, 403. [CrossRef]

145. Sun, J.; Xu, J.; Ling, Y.; Wang, F.; Gong, T.; Yang, C.; Ye, S.; Ye, K.; Wei, D.; Song, Z.; et al. Fecal Microbiota Transplantation Alleviated Alzheimer's Disease-like Pathogenesis in APP/PS1 Transgenic Mice. Transl. Psychiatry 2019, 9, 189. [CrossRef] [PubMed]

146. Kim, D.K.; Park, J.; Han, D.; Yang, J.; Kim, A.; Woo, J.; Kim, Y.; Mook-Jung, I. Molecular and Functional Signatures in a Novel Alzheimer's Disease Mouse Model Assessed by Quantitative Proteomics. Mol. Neurodegener. 2018, 13, 2. [CrossRef]

147. Kim, M.-S.; Kim, Y.; Choi, H.; Kim, W.; Park, S.; Lee, D.; Kim, D.K.; Kim, H.J.; Choi, H.; Hyun, D.-W.; et al. Transfer of a Healthy Microbiota Reduces Amyloid and Tau Pathology in an Alzheimer's Disease Animal Model. Gut 2020, 69, 283-294. [CrossRef] [PubMed]

148. Akbari, E.; Asemi, Z.; Daneshvar Kakhaki, R.; Bahmani, F.; Kouchaki, E.; Tamtaji, O.R.; Hamidi, G.A.; Salami, M. Effect of Probiotic Supplementation on Cognitive Function and Metabolic Status in Alzheimer's Disease: A Randomized, Double-Blind and Controlled Trial. Front. Aging Neurosci. 2016, 8, 256. [CrossRef]

149. Leblhuber, F.; Steiner, K.; Schuetz, B.; Fuchs, D.; Gostner, J.M. Probiotic Supplementation in Patients with Alzheimer's DementiaAn Explorative Intervention Study. Curr. Alzheimer Res. 2018, 15, 1106-1113. [CrossRef]

150. Krüger, J.F.; Hillesheim, E.; Pereira, A.C.S.N.; Camargo, C.Q.; Rabito, E.I. Probiotics for Dementia: A Systematic Review and Meta-Analysis of Randomized Controlled Trials. Nutr. Rev. 2021, 79, 160-170. [CrossRef] 
151. Izzo, A.A.; Muccioli, G.G.; Ruggieri, M.R.; Schicho, R. Endocannabinoids and the Digestive Tract and Bladder in Health and Disease. Handb. Exp. Pharmacol. 2015, 231, 423-447. [CrossRef]

152. Izzo, A.A.; Sharkey, K.A. Cannabinoids and the Gut: New Developments and Emerging Concepts. Pharmacol. Ther. 2010, 126, 21-38. [CrossRef] [PubMed]

153. Mehrpouya-Bahrami, P.; Chitrala, K.N.; Ganewatta, M.S.; Tang, C.; Murphy, E.A.; Enos, R.T.; Velazquez, K.T.; McCellan, J.; Nagarkatti, M.; Nagarkatti, P. Blockade of CB1 Cannabinoid Receptor Alters Gut Microbiota and Attenuates Inflammation and Diet-Induced Obesity. Sci. Rep. 2017, 7, 15645. [CrossRef] [PubMed]

154. Cluny, N.L.; Keenan, C.M.; Reimer, R.A.; Le Foll, B.; Sharkey, K.A. Prevention of Diet-Induced Obesity Effects on Body Weight and Gut Microbiota in Mice Treated Chronically with $\triangle 9$-Tetrahydrocannabinol. PLoS ONE 2015, 10, e0144270. [CrossRef]

155. Geurts, L.; Everard, A.; Van Hul, M.; Essaghir, A.; Duparc, T.; Matamoros, S.; Plovier, H.; Castel, J.; Denis, R.G.; Bergiers, M.; et al. Adipose Tissue NAPE-PLD Controls Fat Mass Development by Altering the Browning Process and Gut Microbiota. Nat. Commun. 2015, 6, 6495. [CrossRef] [PubMed]

156. Yoshida, K.; Kita, Y.; Tokuoka, S.M.; Hamano, F.; Yamazaki, M.; Sakimura, K.; Kano, M.; Shimizu, T. Monoacylglycerol Lipase Deficiency Affects Diet-Induced Obesity, Fat Absorption, and Feeding Behavior in CB1 Cannabinoid Receptor-Deficient Mice. FASEB J. 2019, 33, 2484-2497. [CrossRef] [PubMed]

157. Dione, N.; Lacroix, S.; Taschler, U.; Deschênes, T.; Abolghasemi, A.; Leblanc, N.; Di Marzo, V.; Silvestri, C. Mgll Knockout Mouse Resistance to Diet-Induced Dysmetabolism Is Associated with Altered Gut Microbiota. Cells 2020, 9, 2705. [CrossRef] [PubMed]

158. Muccioli, G.G.; Naslain, D.; Backhed, F.; Reigstad, C.S.; Lambert, D.M.; Delzenne, N.M.; Cani, P.D. The Endocannabinoid System Links Gut Microbiota to Adipogenesis. Mol. Syst. Biol. 2010, 6, 392. [CrossRef]

159. Aguilera, M.; Vergara, P.; Martínez, V. Stress and Antibiotics Alter Luminal and Wall-Adhered Microbiota and Enhance the Local Expression of Visceral Sensory-Related Systems in Mice. Neurogastroenterol. Motil. 2013, 25, e515-e529. [CrossRef]

160. Rousseaux, C.; Thuru, X.; Gelot, A.; Barnich, N.; Neut, C.; Dubuquoy, L.; Dubuquoy, C.; Merour, E.; Geboes, K.; Chamaillard, M.; et al. Lactobacillus Acidophilus Modulates Intestinal Pain and Induces Opioid and Cannabinoid Receptors. Nat. Med. 2007, 13, 35-37. [CrossRef]

161. Manca, C.; Boubertakh, B.; Leblanc, N.; Deschênes, T.; Lacroix, S.; Martin, C.; Houde, A.; Veilleux, A.; Flamand, N.; Muccioli, G.G.; et al. Germ-Free Mice Exhibit Profound Gut Microbiota-Dependent Alterations of Intestinal Endocannabinoidome Signaling. J. Lipid Res. 2020, 61, 70-85. [CrossRef]

162. Chevalier, G.; Siopi, E.; Guenin-Macé, L.; Pascal, M.; Laval, T.; Rifflet, A.; Boneca, I.G.; Demangel, C.; Colsch, B.; Pruvost, A.; et al. Effect of Gut Microbiota on Depressive-like Behaviors in Mice Is Mediated by the Endocannabinoid System. Nat. Commun. 2020, 11, 6363. [CrossRef]

163. Payahoo, L.; Khajebishak, Y.; Alivand, M.R.; Soleimanzade, H.; Alipour, S.; Barzegari, A.; Ostadrahimi, A. Investigation the Effect of Oleoylethanolamide Supplementation on the Abundance of Akkermansia Muciniphila Bacterium and the Dietary Intakes in People with Obesity: A Randomized Clinical Trial. Appetite 2019, 141, 104301. [CrossRef]

164. Cani, P.D.; de Vos, W.M. Next-Generation Beneficial Microbes: The Case of Akkermansia Muciniphila. Front. Microbiol. 2017, 8, 1765. [CrossRef] [PubMed]

165. Depommier, C.; Vitale, R.M.; Iannotti, F.A.; Silvestri, C.; Flamand, N.; Druart, C.; Everard, A.; Pelicaen, R.; Maiter, D.; Thissen, J.-P.; et al. Beneficial Effects of Akkermansia Muciniphila Are Not Associated with Major Changes in the Circulating Endocannabinoidome but Linked to Higher Mono-Palmitoyl-Glycerol Levels as New PPAR $\alpha$ Agonists. Cells 2021, 10, 185. [CrossRef]

166. Everard, A.; Belzer, C.; Geurts, L.; Ouwerkerk, J.P.; Druart, C.; Bindels, L.B.; Guiot, Y.; Derrien, M.; Muccioli, G.G.; Delzenne, N.M.; et al. Cross-Talk between Akkermansia Muciniphila and Intestinal Epithelium Controls Diet-Induced Obesity. Proc. Natl. Acad. Sci. USA 2013, 110, 9066-9071. [CrossRef]

167. Minichino, A.; Jackson, M.A.; Francesconi, M.; Steves, C.J.; Menni, C.; Burnet, P.W.J.; Lennox, B.R. Endocannabinoid System Mediates the Association between Gut-Microbial Diversity and Anhedonia/Amotivation in a General Population Cohort. Mol. Psychiatry 2021, 1365, 1-8. [CrossRef]

168. Castonguay-Paradis, S.; Lacroix, S.; Rochefort, G.; Parent, L.; Perron, J.; Martin, C.; Lamarche, B.; Raymond, F.; Flamand, N.; Di Marzo, V.; et al. Dietary Fatty Acid Intake and Gut Microbiota Determine Circulating Endocannabinoidome Signaling beyond the Effect of Body Fat. Sci. Rep. 2020, 10, 15975. [CrossRef] [PubMed]

169. Forte, N.; Fernández-Rilo, A.C.; Palomba, L.; Di Marzo, V.; Cristino, L. Obesity Affects the Microbiota-Gut-Brain Axis and the Regulation Thereof by Endocannabinoids and Related Mediators. Int. J. Mol. Sci. 2020, 21, 1554. [CrossRef] [PubMed]

170. Cooray, R.; Gupta, V.; Suphioglu, C. Current Aspects of the Endocannabinoid System and Targeted THC and CBD Phytocannabinoids as Potential Therapeutics for Parkinson's and Alzheimer's Diseases: A Review. Mol. Neurobiol. 2020, 57, 4878-4890. [CrossRef] [PubMed]

171. Benito, C.; Núñez, E.; Tolón, R.M.; Carrier, E.J.; Rábano, A.; Hillard, C.J.; Romero, J. Cannabinoid CB2 Receptors and Fatty Acid Amide Hydrolase Are Selectively Overexpressed in Neuritic Plaque-Associated Glia in Alzheimer's Disease Brains. J. Neurosci. 2003, 23, 11136-11141. [CrossRef] [PubMed]

172. Núñez, E.; Benito, C.; Pazos, M.R.; Barbachano, A.; Fajardo, O.; González, S.; Tolón, R.M.; Romero, J. Cannabinoid CB2 Receptors Are Expressed by Perivascular Microglial Cells in the Human Brain: An Immunohistochemical Study. Synapse 2004, 53, $208-213$. [CrossRef] 
173. Manuel, I.; González de San Román, E.; Giralt, M.T.; Ferrer, I.; Rodríguez-Puertas, R. Type-1 Cannabinoid Receptor Activity during Alzheimer's Disease Progression. J. Alzheimer's Dis. 2014, 42, 761-766. [CrossRef]

174. Esposito, G.; De Filippis, D.; Steardo, L.; Scuderi, C.; Savani, C.; Cuomo, V.; Iuvone, T. CB1 Receptor Selective Activation Inhibits Beta-Amyloid-Induced INOS Protein Expression in C6 Cells and Subsequently Blunts Tau Protein Hyperphosphorylation in Co-Cultured Neurons. Neurosci. Lett. 2006, 404, 342-346. [CrossRef]

175. Dockray, G.J. Enteroendocrine Cell Signalling via the Vagus Nerve. Curr. Opin. Pharmacol. 2013, 13, 954-958. [CrossRef] [PubMed]

176. Jansma, J.; Brinkman, F.; van Hemert, S.; El Aidy, S. Targeting the Endocannabinoid System with Microbial Interventions to Improve Gut Integrity. Prog. Neuropsychopharmacol. Biol. Psychiatry 2021, 106, 110169. [CrossRef] [PubMed]

177. Guillemot-Legris, O.; Muccioli, G.G. Obesity-Induced Neuroinflammation: Beyond the Hypothalamus. Trends Neurosci. 2017, 40, 237-253. [CrossRef] [PubMed]

178. Lloret, A.; Monllor, P.; Esteve, D.; Cervera-Ferri, A.; Lloret, M.-A. Obesity as a Risk Factor for Alzheimer's Disease: Implication of Leptin and Glutamate. Front. Neurosci. 2019, 13, 508. [CrossRef]

179. Kivipelto, M.; Ngandu, T.; Fratiglioni, L.; Viitanen, M.; Kåreholt, I.; Winblad, B.; Helkala, E.-L.; Tuomilehto, J.; Soininen, H.; Nissinen, A. Obesity and Vascular Risk Factors at Midlife and the Risk of Dementia and Alzheimer Disease. Arch. Neurol. 2005, 62, 1556-1560. [CrossRef] [PubMed]

180. Payabvash, S.; Souza, L.C.S.; Wang, Y.; Schaefer, P.W.; Furie, K.L.; Halpern, E.F.; Gonzalez, R.G.; Lev, M.H. Regional Ischemic Vulnerability of the Brain to Hypoperfusion: The Need for Location Specific Computed Tomography Perfusion Thresholds in Acute Stroke Patients. Stroke 2011, 42, 1255-1260. [CrossRef]

181. Arnoldussen, I.A.C.; Kiliaan, A.J.; Gustafson, D.R. Obesity and Dementia: Adipokines Interact with the Brain. Eur. Neuropsychopharmacol. 2014, 24, 1982-1999. [CrossRef]

182. Kiliaan, A.J.; Arnoldussen, I.A.C.; Gustafson, D.R. Adipokines: A Link between Obesity and Dementia? Lancet Neurol. 2014, 13, 913-923. [CrossRef]

183. McGuire, M.J.; Ishii, M. Leptin Dysfunction and Alzheimer's Disease: Evidence from Cellular, Animal, and Human Studies. Cell Mol. Neurobiol. 2016, 36, 203-217. [CrossRef]

184. Lieb, W.; Beiser, A.S.; Vasan, R.S.; Tan, Z.S.; Au, R.; Harris, T.B.; Roubenoff, R.; Auerbach, S.; DeCarli, C.; Wolf, P.A.; et al. Association of Plasma Leptin Levels with Incident Alzheimer Disease and MRI Measures of Brain Aging. JAMA 2009, 302, 2565-2572. [CrossRef] [PubMed]

185. Greco, S.J.; Bryan, K.J.; Sarkar, S.; Zhu, X.; Smith, M.A.; Ashford, J.W.; Johnston, J.M.; Tezapsidis, N.; Casadesus, G. Leptin Reduces Pathology and Improves Memory in a Transgenic Mouse Model of Alzheimer's Disease. J. Alzheimer's Dis. 2010, 19, 1155-1167. [CrossRef] [PubMed]

186. Di Marzo, V.; Goparaju, S.K.; Wang, L.; Liu, J.; Batkai, S.; Jarai, Z.; Fezza, F.; Miura, G.I.; Palmiter, R.D.; Sugiura, T.; et al. Leptin-Regulated Endocannabinoids Are Involved in Maintaining Food Intake. Nature 2001, 410, 822-825. [CrossRef] [PubMed]

187. Jo, Y.-H.; Chen, Y.-J.J.; Chua, S.C.; Talmage, D.A.; Role, L.W. Integration of Endocannabinoid and Leptin Signaling in an Appetite-Related Neural Circuit. Neuron 2005, 48, 1055-1066. [CrossRef]

188. Chen, R.; Zhang, J.; Wu, Y.; Wang, D.; Feng, G.; Tang, Y.-P.; Teng, Z.; Chen, C. Monoacylglycerol Lipase Is a Therapeutic Target for Alzheimer's Disease. Cell Rep. 2012, 2, 1329-1339. [CrossRef]

189. Pihlaja, R.; Takkinen, J.; Eskola, O.; Vasara, J.; López-Picón, F.R.; Haaparanta-Solin, M.; Rinne, J.O. Monoacylglycerol Lipase Inhibitor JZL184 Reduces Neuroinflammatory Response in APdE9 Mice and in Adult Mouse Glial Cells. J. Neuroinflamm. 2015, 12, 81. [CrossRef]

190. Grabner, G.F.; Eichmann, T.O.; Wagner, B.; Gao, Y.; Farzi, A.; Taschler, U.; Radner, F.P.W.; Schweiger, M.; Lass, A.; Holzer, P.; et al. Deletion of Monoglyceride Lipase in Astrocytes Attenuates Lipopolysaccharide-Induced Neuroinflammation. J. Biol. Chem. 2016, 291, 913-923. [CrossRef]

191. Piro, J.R.; Benjamin, D.I.; Duerr, J.M.; Pi, Y.; Gonzales, C.; Wood, K.M.; Schwartz, J.W.; Nomura, D.K.; Samad, T.A. A Dysregulated Endocannabinoid-Eicosanoid Network Supports Pathogenesis in a Mouse Model of Alzheimer's Disease. Cell Rep. 2012, 1, 617-623. [CrossRef] 